medRxiv preprint doi: https://doi.org/10.1101/2021.07.20.21259482; this version posted July 20, 2021. The copyright holder for this preprint (which was not certified by peer review) is the author/funder, who has granted medRxiv a license to display the preprint in perpetuity.

It is made available under a CC-BY 4.0 International license .

\title{
Genetic, structural and clinical analysis of spastic paraplegia 4
}

Parizad Varghaei ${ }^{1,2}$, MD, Mehrdad A Estiar ${ }^{2,3}$, MSc, Setareh Ashtiani ${ }^{4}$, MSc, Simon Veyron ${ }^{5}$, $\mathrm{PhD}$, Kheireddin Mufti ${ }^{2,3}, \mathrm{MSc}$, Etienne Leveille ${ }^{6}, \mathrm{MD}$, Eric Yu ${ }^{2,3}, \mathrm{BSc}$, Dan Spiegelman, MSc ${ }^{2}$, Marie-France Rioux ${ }^{7}$, MD, Grace Yoon $^{8}$, MD, Mark Tarnopolsky ${ }^{9}$, MD, PhD, Kym M. Boycott $^{10}$, MD, Nicolas Dupre ${ }^{11,12}$, MD, MSc, Oksana Suchowersky ${ }^{4,13}$, MD, Jean-François Trempe ${ }^{5}, \mathrm{PhD}$, Guy A. Rouleau ${ }^{2,3,14}, \mathrm{MD}, \mathrm{PhD}, \mathrm{Ziv}$ Gan-Or ${ }^{2,3,14}, \mathrm{MD}, \mathrm{PhD}$

1. Division of Experimental Medicine, Department of Medicine, McGill University, Montreal, Quebec, Canada

2. The Neuro (Montreal Neurological Institute-Hospital), McGill University, Montreal, Quebec, Canada

3. Department of Human Genetics, McGill University, Montréal, Québec, Canada

4. Alberta Children's Hospital, Medical Genetics, Calgary, Alberta, Canada

5. Department of Pharmacology \& Therapeutics and Centre de Recherche en Biologie Structurale - FRQS, McGill University, Montréal, Canada

6. Faculty of Medicine, McGill University, Montreal, QC, Canada

7. Department of Neurology, Université de Sherbrooke, Sherbrooke, Québec, Canada.

8. Divisions of Neurology and Clinical and Metabolic Genetics, Department of Paediatrics, University of Toronto, The Hospital for Sick Children, Toronto, Ontario, Canada

9. Department of Pediatrics, McMaster University, Hamilton, Ontario, Canada

10. Children's Hospital of Eastern Ontario Research Institute, University of Ottawa, Ottawa, Ontario, Canada

11. Department of Medicine, Faculty of Medicine, Université Laval, Québec City, Quebec, Canada

12. Neuroscience Axis, CHU de Québec-Université Laval, Québec City, Québec, Canada

13. Departments of Medicine (Neurology) and Medical Genetics, University of Alberta, Edmonton, Alberta, Canada

14. Department of Neurology and Neurosurgery, McGill University, Montréal, Québec, Canada

Correspondence to:

Guy A. Rouleau,

Director, Montréal Neurological Institute and hospital,

Address: 3801, University Street, Office 636

Montréal, Québec H3A 2B4

Phone: +1-514-398-2690,

Fax. +1-514 398-8248

Email: guy.rouleau@mcgill.ca

Ziv Gan-Or

Department of Neurology and Neurosurgery

McGill University

1033 Pine Avenue, West,

Ludmer Pavilion, room 312

Montreal, QC, H3A 1A1,

NOTE: This preprint reports new research that has not been certified by peer review and should not be used to guide clinical practice. 
Phone: $+1-514-398-5845$

Fax. +1-514 398-8248

Email: ziv.gan-or@mcgill.ca

Word count: 3689

Running title: Genetic, structural and clinical aspects of SPG4

Keywords: Spastic paraplegia, HSP, SPG4, SPAST

Relevant conflicts of interest/financial disclosures: The authors report no competing interests.

Funding sources for the study: This study was funded by CIHR Emerging Team Grant, in collaboration with the Canadian Organization for Rare Disorders (CORD), grant number RN127580 - 260005, and by a CIHR Foundation grant granted to GAR. MAE is funded by the Fonds de Recherche du Québec-Santé (FRQS). GAR holds the Wilder Penfield Chair in Neurosciences. ZGO is supported by the Fonds de recherche du Québec-Santé ChercheurBoursier award and is a William Dawson Scholar. 
medRxiv preprint doi: https://doi.org/10.1101/2021.07.20.21259482; this version posted July 20, 2021. The copyright holder for this preprint (which was not certified by peer review) is the author/funder, who has granted medRxiv a license to display the preprint in perpetuity.

It is made available under a CC-BY 4.0 International license.

\begin{abstract}
Background: Spastic paraplegia type 4 (SPG4), resulting from heterozygous mutations in the SPAST gene, is the most common form among the heterogeneous group of hereditary spastic paraplegias (HSPs).
\end{abstract}

Objective: To study genetic and clinical characteristics of SPG4 across Canada.

Methods: The SPAST gene was analyzed in a total of 696 HSP patients from 431 families by either HSP-gene panel sequencing or whole exome sequencing (WES). We used Multiplex ligation-dependent probe amplification to analyze copy number variations (CNVs), and performed in silico structural analysis of selected mutations. Clinical characteristics of patients were assessed, and long-term follow-up was done to study genotype-phenotype correlations.

Results: We identified 157 SPG4 patients from 65 families who carried 41 different SPAST mutations, six of which are novel and six are CNVs. We report novel aspects of mutations occurring in Arg499, a case with homozygous mutation, a family with probable compound heterozygous mutations, three patients with de novo mutations, three cases with pathogenic synonymous mutation, co-occurrence of SPG4 and multiple sclerosis, and novel or rarely reported signs and symptoms seen in SPG4 patients.

Conclusion: Our study demonstrates that SPG4 is a heterogeneous type of HSP, with diverse genetic features and clinical manifestations. In rare cases, biallelic inheritance, de novo mutation, pathogenic synonymous mutations and CNVs should be considered. 
medRxiv preprint doi: https://doi.org/10.1101/2021.07.20.21259482; this version posted July 20, 2021. The copyright holder for this preprint (which was not certified by peer review) is the author/funder, who has granted medRxiv a license to display the preprint in perpetuity.

It is made available under a CC-BY 4.0 International license .

\section{Introduction}

Spastic paraplegia type 4 (SPG4, OMIM \#182601) is the most frequent form of either sporadic or familial hereditary spastic paraplegias (HSPs), caused by heterozygous mutations in the SPAST gene. ${ }^{1-3}$ With more than 80 potentially causative loci or genes reported to date, ${ }^{4}$ HSPs are known to affect $1-10 / 100,000$ of the population, ${ }^{5}$ and autosomal dominant (AD) HSPs comprise 43\%-80\% of them..$^{5-11}$ Among all AD-HSPs, 70-80\% are categorized as "pure"12 with a phenotype limited to pyramidal signs in the lower limbs, with or without deep sensory loss and sphincter disturbances. ${ }^{12-15}$ Of all pure AD-HSPs, about $40 \%$ are caused by SPAST mutations. ${ }^{12}$

SPAST encodes spastin, which is a protein from the AAA (ATPase associated with various cellular activities) family of ATPases. ${ }^{16,17}$ Spastin controls different aspects of microtubule dynamics (e.g. microtubule number, motility, length, disassembly and remodeling), and hydrolyses ATP to cleave microtubules, ${ }^{18,}{ }^{19}$ a necessary step in axonal transport. ${ }^{20}$ Its mechanism involves binding to the C-terminus of tubulin and severing tubulin subunits from the microtubule in an ATP hydrolysis-dependent manner. ${ }^{19}$ The structure of human spastin residues 323-610 was solved by cryoelectron microscopy. ${ }^{21}$ The structure reveals an AAA+ ATPase homohexamer (Figure 1A), with ATPase active sites located at the interface between every adjacent subunit (Figure 1B). ${ }^{22,23}$ A tubulin peptide runs through the channel, suggesting a handover-hand mechanism of substrate translocation, with five subunits interacting with the peptide forming a spiral staircase and one displaced from the peptide/substrate (Figure 1A). ${ }^{21}$

To date, more than 200 SPAST mutations have been found. ${ }^{3,16,24-26}$ Deletion/insertions, nonsense, and splice site mutations are distributed throughout the gene, while missense mutations are mostly clustered in the AAA domain. ${ }^{3}$ Exon deletions may account for $20 \%$ of cases in whom point mutations are not detected. ${ }^{27,28}$ 
medRxiv preprint doi: https://doi.org/10.1101/2021.07.20.21259482; this version posted July 20, 2021. The copyright holder for this preprint (which was not certified by peer review) is the author/funder, who has granted medRxiv a license to display the preprint in perpetuity.

It is made available under a CC-BY 4.0 International license .

The penetrance of SPG4 is up to $80-90 \%$ and is age-dependent, ${ }^{3}$ with age at onset (AAO) that may range from infancy to the eighth decade of life. ${ }^{1,29}$ Most cases present as juvenile or adult-onset pure spastic paraplegia with urinary sphincter disturbances, pes cavus, and dysarthria. However, SPAST mutations are known to cause clinically heterogeneous manifestations, and a high variety of signs and symptoms is reported among carriers of different SPAST mutations. This clinical heterogeneity occurs even among patients harboring the same mutations, ${ }^{30}$ suggesting that other factors affect the clinical presentation of SPG4.

Although previous studies have deciphered some aspects of this variability, the genotypephenotype correlations and some rare features of SPG4 are not fully understood. In this study, we analyzed a large cohort of SPG4 patients from Canada to better clarify the genetic and clinical spectrum of the disease.

\section{Methods}

\section{Population}

A total of 696 HSP patients from 431 families were recruited in eight medical centers across Canada (Montreal, Quebec, Ottawa, Toronto, Hamilton, Calgary, Edmonton, and Vancouver) as part of CanHSP, a Canadian consortium for the study of HSP. Details about the diagnosis and recruitment process has been previously reported. ${ }^{31}$ Clinical assessments were done including family history, demographic data, developmental history, AAO, and HSP core symptoms (lower extremity weakness and spasticity, extensor plantar responses, hyperreflexia, and bladder dysfunction). Other neurological, as well as non-neurological clinical presentations of HSP, were also assessed. For a group of the patients, the Spastic Paraplegia Rating Scale (SPRS), which is 
medRxiv preprint doi: https://doi.org/10.1101/2021.07.20.21259482; this version posted July 20, 2021. The copyright holder for this preprint (which was not certified by peer review) is the author/funder, who has granted medRxiv a license to display the preprint in perpetuity.

It is made available under a CC-BY 4.0 International license .

an indicator of severity in HSP, was measured. ${ }^{32,33}$ For another subset of patients, brain and/or spine MRI were performed. The disease was deemed pure unless the patient had at least one sign not attributable to the lateral corticospinal tract or pyramidal tract, including ataxia, intellectual disability, cognitive decline, language development delay, extrapyramidal signs, visual dysfunction, epilepsy, deafness, dysarthria, optic atrophy, peripheral neuropathy, and dystonia; in which case the disease was classified as complex.

All the data is stored in a central database at McGill University. All patients signed informed consent forms and the institutional review board approved the study protocol.

\section{Genetic and data analysis}

DNA was extracted from peripheral blood using a standard procedure. ${ }^{34}$ Initially, HSP-gene panel sequencing was performed on 379 patients. Then, 194 genetically undiagnosed patients, and additional 206 patients who were not analyzed with panel sequencing (400 patients in total from 291 families), went through whole exome sequencing (WES).

For WES, the Agilent SureSelect Human All Exon v4 kit for capture and targeted enrichment of the exome was used. To analyze the WES data, we used a list of 785 HSP-related genes or genes associated with similar neurological disorders which cause spasticity (Supplementary Table 1). Illumina HiSeq 2000/2500/4000 system was used for sequencing captured samples. Using Burrows-Wheeler Aligner (BWA), the sequence reads were then aligned against the human genome (GRCh37 assembly). ${ }^{35}$ We used the Genome Analysis ToolKit $(\mathrm{GATK})^{36}$ and Annotate Variation (ANNOVAR) ${ }^{37}$ for variant calling and annotation, respectively. We excluded variant calls with a genotype quality less than 97 and less than 30x depth of coverage. Integrated Genomics Viewer was used to visually inspect the detected 
medRxiv preprint doi: https://doi.org/10.1101/2021.07.20.21259482; this version posted July 20, 2021. The copyright holder for this preprint (which was not certified by peer review) is the author/funder, who has granted medRxiv a license to display the preprint in perpetuity.

It is made available under a CC-BY 4.0 International license.

variants, and suspicious variants were validated by Sanger Sequencing. Sanger Sequencing was also used for assessing sporadic patients' parents, to determine if the proband had a de novo mutation.

SPAST variants (NM_014946) were initially selected based on identifying missense and LoF alleles, including frame-shift, splice-site, nonsense, and copy number variations (CNVs) with a minor allele frequency less than 0.01 in gnomAD. ${ }^{38}$ The variants' pathogenicity has been determined using VarSome, ${ }^{39}$ according to the American College of Medical Genetics and Genomics (ACMG) guideline. Variants classified as "Benign" and "Likely Benign", as well as intronic splice site variants higher than \pm 3 were excluded from the analysis. To detect CNVs, ExomeDepth $^{40}$ was used on WES data, followed by 48 selected samples that went through Multiplex ligation-dependent probe amplification (MLPA) testing (MRC Holland, Amsterdam, The Netherlands) to confirm or exclude suspected SPAST CNVs. InterPro ${ }^{41}$ was applied to identify domains and corresponding sites in the protein.

\section{Statistical analysis}

To determine the association between two categorical variables, one categorical variable with one continuous variable, and two continuous variables, Pearson chi-squared test, Mann-Whitney U test, and Spearman's rank correlation coefficient were used, respectively. $P$-value was set at $<0.05$ and Bonferroni correction for multiple comparisons was applied when necessary. SPSS was used to perform all statistical analyses.

\section{In silico structural analysis}

The atomic coordinates of human spastin bound to a glutamate-rich peptide, $\mathrm{ADP}, \mathrm{BeF}_{3}$ and $\mathrm{Mg}^{2+}$ and D. melanogaster spastin bound to a glutamate-rich peptide, ADP, ATP and $\mathrm{Mg}^{2+}$ were 
medRxiv preprint doi: https://doi.org/10.1101/2021.07.20.21259482; this version posted July 20, 2021. The copyright holder for this preprint (which was not certified by peer review) is the author/funder, who has granted medRxiv a license to display the preprint in perpetuity.

It is made available under a CC-BY 4.0 International license.

downloaded from the Protein Data Bank (ID 6PEN and 6P07). The effect induced by each mutation was evaluated using the "mutagenesis" toolbox in The PyMOL Molecular Graphics System, Version 2.4.0 Schrödinger, LLC. and the DynaMut server http://biosig.unimelb.edu.au/dynamut/. ${ }^{42}$

\section{Results}

\section{Cohort characteristics}

We identified 65 families (15.1\% of the families in HSP cohort), and a total of 157 patients (22.5\% of HSP patients) with SPG4. Mean AAO was 22 years (0-67, SD: 19.89), and it followed a bimodal distribution; the first peak in the first 5 years of life, and the second peak from 35 to 44 years of age (Supplementary Figure 1). Mean age at examination was 43.4, and mean disease duration was 21 years. Patients with longer disease duration presented with higher SPRS scores (Spearman's correlation coefficient; $p=0.048$ ). In contrast, age at onset was not associated with the severity of the disease (Spearman's correlation coefficient; $p=0.934$ ). Complex HSP was seen in $24 / 65(36.9 \%)$ of the probands, and 37/157 (23.6\%) of all the patients. No significant differences were seen between male and female patients in AAO and other clinical manifestations. Table 1 details the clinical presentation of the patients.

We detected 41 different SPAST mutations in our cohort (Table 2). Most mutations $(22 / 34,64.7 \%)$ occurred between amino acids 374 and 567, in the AAA cassette. Among the missense mutations, 15/20 (75\%) were clustered in AAA cassette, while LoF mutations were more evenly distributed across gene (Figure 2). Presentation of the disease did not differ significantly between the two types of mutation (Table 1). 
medRxiv preprint doi: https://doi.org/10.1101/2021.07.20.21259482; this version posted July 20, 2021. The copyright holder for this preprint

\section{Novel SPAST mutations}

Of the 41 different SPAST mutations in our cohort, six were novel, including p.(Trp77Ter), p.(Glu366AspfsTer28), p.(Gly382_Pro383insArg), p.(Phe403Leu), p.(Arg498AlafsTer30), and p.(Ser597ThrfsTer3). We performed in silico analysis to investigate the impact of these mutations on the structure and activity of spastin, with exception of p.(Trp77Ter), as Trp77 is not visible in any structure of spastin and could not be investigated.

Glu366 is located in the loop $365-377$ and the frameshift mutation p.(Glu366AspfsTer28) changes all the residue subsequent to residue 365 and inserts a stop codon at position 394 . This mutation truncates residues 394 to 616 which includes residues involved in oligomerization and ATP-binding, which will abrogate its enzymatic activity. Gly382 and Pro383 are located in the nucleotide-binding loop $382-389 .{ }^{43}$ Residues Gly385 and Asn386 interact directly with the ADP, in a conformation that is shaped by the Pro383 and Pro384 (Figure 1C). The mutation p.(Gly382_Pro383insArg) lengthens this loop and likely destabilizes the interaction between the protein and the nucleotide. Phe403 forms a pi-stacking interaction with Phe439 and hydrophobic interactions with neighbouring residues (Figure 1D). Thus, mutation p.(Phe403Leu) would destabilize the domain and impair the ATPase activity.

In this structure, Arg498 and Arg499 are both involved in coordinating ADP. Arg498 is making direct interaction with the $\beta$ phosphate of the nucleotide located in the active site, while Arg499 stabilizes helix $455-470$ and coordinates $\mathrm{BeF}_{3}$, a phosphate structural analog (Figure 1E). By homology with D. melanogaster spastin structure (PDB ID: 6P07), those residues seem to be also involved in ATP $\beta$ and $\gamma$ phosphate coordination (Figure 1F). As a result, we can 
medRxiv preprint doi: https://doi.org/10.1101/2021.07.20.21259482; this version posted July 20, 2021. The copyright holder for this preprint (which was not certified by peer review) is the author/funder, who has granted medRxiv a license to display the preprint in perpetuity.

It is made available under a CC-BY 4.0 International license.

hypothesize that the $\mathrm{BeF}_{3}$ in the active site is mimicking the $\gamma$ phosphate on an ATP. Mutation p.(Arg498AlafsTer30) causes residues 498 and 499 to be serine and valine residues, which would prevent ATP stabilization. In addition, this frame shift terminates the protein after residue 528, further disrupting the ATP-binding domain. This mutation will therefore abolish the ATPase activity. Finally, mutation p.(Ser597ThrfsTer3) will induce a frame shift at residue 597 and truncate the protein at residue 600 . The missing C-terminal residues form a helix involved in intersubunit interactions. This mutation would therefore destabilize the hexameric assembly, which would disrupt the ATPase activity.

\section{Founder French-Canadian mutations and known CNVs}

The most frequent SPAST mutation in our cohort, p.(Gly559Asp), which has previously been suggested to be a founder mutation in French-Canadian population ${ }^{44}$, was carried by 8 families $(12.3 \%)$ and 15 patients in total (9.5\%). Seven out of 24 French-Canadian probands (29\%) harbored this mutation, while among all the patients with other or unknown ancestral backgrounds, this mutation was present in only one out of 29 probands $(3.4 \%, p=0.011)$. Moreover, the mutation p.(Phe403Leu) was only detected in patients with French-Canadian ancestral background, in 5 patients from 2 families, suggesting it may be a founder mutation. Seven patients $(4.5 \%)$ from six families (9.2\%) carried a CNV (Supplementary Table 2), all of which have been previously reported. ${ }^{27}$

Earlier age at onset and specific clinical features in patients with mutations in SPAST p.Arg499 
medRxiv preprint doi: https://doi.org/10.1101/2021.07.20.21259482; this version posted July 20, 2021. The copyright holder for this preprint (which was not certified by peer review) is the author/funder, who has granted medRxiv a license to display the preprint in perpetuity.

It is made available under a CC-BY 4.0 International license.

The range of AAO in all 4 patients from 4 different families, two of which have previously been reported $^{45}$ with the p.(Arg499His) mutation was 1-3 years (Mann-Whitney U test; $p=0.003$ ). The age range at which these four patients started to show symptoms was 1-5. Patients with this mutation in our cohort were more likely to present with motor delay, speech delay, dysarthria, learning disability, progressive cognitive deficits, and upper extremity weakness (Supplementary Table3).

Although statistically insignificant, cases who carried another mutation affecting the same amino acid residue, p.(Arg499Cys), also showed symptoms at a younger age (the range of AAO was 1-5 in three patients and 11-15 in one patient, $p=0.111$ ). When combined together, the two mutations occurred in Arg499 locus were associated with a younger AAO (MannWhitney U test; $p=0.004)$. In silico analysis of Arg499 is discussed above, along with Arg498. Furthermore, as Arg499 stabilizes the $\gamma$ phosphate, mutations p.(Arg499Cys) or p.(Arg499His) would also impede ATP binding and catalysis.

\section{Possible biallelic inheritance in SPG4}

The SPAST p.(Ser44Leu) variant has been previously suggested to play modifier role in SPG4. ${ }^{1}$ 46, 47 This variant was detected in one out of the 36 families that had undergone WES. From the three affected siblings, two had undergone WES, and both were heterozygous for the novel pathogenic mutation p.(Ser597ThrfsTer3), as well as for the p.(Ser44Leu) variant. The three siblings had complex HSP with disease onset in early childhood (clinical presentation of these patients is detailed in Supplementary Table 4). One unaffected parent only carried the p.(Ser44Leu) polymorphism, and the other unaffected parent was heterozygous for the 
medRxiv preprint doi: https://doi.org/10.1101/2021.07.20.21259482; this version posted July 20, 2021. The copyright holder for this preprint (which was not certified by peer review) is the author/funder, who has granted medRxiv a license to display the preprint in perpetuity.

It is made available under a CC-BY 4.0 International license.

pathogenic p.(Ser597ThrfsTer3) mutation and wild-type for p.(Ser44Leu) (Supplementary Figure

2). The last physical examination of the parent with the pathogenic mutation at the age between 56 to 60 revealed completely normal findings, including normal reflexes, gait, and motor exam, suggesting that the p.(Ser44Leu) variant may be a modifier of the disease, or that extreme anticipation with undetected clinical effects in the mother exist in this family.

Another patient with consanguineous parents, carried a homozygous mutation, SPAST p.(Tyr51Ter). The patient had started to show symptoms at an age range of 1-5 years and suffered from core HSP symptoms, motor and speech delay, swallowing difficulty, dysarthria, upper extremity weakness, pes cavus, and skeletal abnormalities. Her brain and total spine MRI were normal and her SPRS score was 40 when examined at an age between 16 and 20 years. The patient's parents were both asymptomatic heterozygous carriers.

\section{Patients with novel or rarely reported clinical manifestations}

In our cohort, four patients (Supplementary Table 5) presented with deafness, one of whom had a de novo SPAST p.(Arg499His) mutation, and the remaining three had familial SPG4. We also report a patient with ocular movement abnormality, in whom extraocular movements showed slightly hypometric saccades but pursuit was smooth, and a mild horizontal gaze evoked rotatory nystagmus. The disease-causing mutation in this patient was p.(Gln434Ter).

One of the signs less reported to date in SPG4 is upper extremity intention tremor, seen in two of the patients in the current study. The causative mutations in these two patients were p.(Arg503Trp) and p.(Leu371Pro). Their respective range of AAO was 46-50 and 26-30, and both presented with a severe form of the disease (respective SPRS scores: 34 and 39). The first 
medRxiv preprint doi: https://doi.org/10.1101/2021.07.20.21259482; this version posted July 20, 2021. The copyright holder for this preprint (which was not certified by peer review) is the author/funder, who has granted medRxiv a license to display the preprint in perpetuity.

It is made available under a CC-BY 4.0 International license.

patient also had swallowing difficulty and peripheral neuropathy, and both had upper extremity ataxia.

Another clinical feature seen in two of the patients in our cohort was seizures, which is quite rare in SPG4. One of the patients of who carried the mutation p.(Pro489Leu), had a range of AAO of 21-25 years, and suffered from generalized seizures starting at 41-45 years of age. The second patient harbored the splice-site mutation c.1321+1G>A, with AAO of between 1 and 5 years, had episodes of atypical seizures at 56-60.

\section{De novo cases}

The parents of the three sporadic cases in our cohort did not carry the causative SPAST mutations. The first patient, with SPAST p.(Ser407Asn), had an AAO of 1-5 years. This case presented with lower extremity weakness and spasticity, upper and lower limb hyperreflexia, extensor plantar response, ankle clonus, and sensory abnormalities. She also showed signs of upper extremity weakness, motor and speech delay, dysarthria, learning disability, and swallowing difficulty. Their brain MRI was normal. The second patient had de novo SPAST p.(Arg499His). This patient started to show symptoms at age range of $1-5$, and her symptoms included lower extremity weakness, spasticity and hyperreflexia, extensor plantar responses, and ankle clonus. Furthermore, they had motor and speech delay, dysarthria, and learning disability. They had a normal brain MRI, and their SPRS score was 37. The last de novo patient, also with a p.(Arg499His) mutation, also with an AAO range of 1-5 years, had an SPRS score of 28, and apart from core symptoms of HSP, had motor and speech delay, deafness, and dysarthria. The two latter patients have been previously reported. ${ }^{45}$ 
medRxiv preprint doi: https://doi.org/10.1101/2021.07.20.21259482; this version posted July 20, 2021. The copyright holder for this preprint

\section{Cases with synonymous mutation and co-occurrence of multiple sclerosis and SPG4}

We report three patients from two unrelated families who carried the synonymous mutation SPAST p.(Lys414Lys), previously reported to be pathogenic. ${ }^{48}$ The first patient had an AAO of between 6-10 years, and presented with lower extremity spasticity, hyperreflexia, and extensor plantar responses. The second family had two affected individuals, parent and offspring. The parent started to have difficulty walking at the age of 61-65 which led to using a cane, had marked spasticity and brisk reflexes in the lower limbs along with ankle clonus, upgoing plantar responses, urge incontinency, and mild decrease of vibration sensation in the ankles and toes. The offspring noticed difficulty walking at 21-25 years of age, which progressed slowly. This case had upper and lower limb weakness, bilateral Babinski sign and ankle clonus, and positive Hoffman sign. At an age between 31 and 35, lumbar puncture carried out due to diplopia was positive for oligoclonal bands and suggested a diagnosis of clinically isolated syndrome (CIS), which is considered as the first clinical episode in multiple sclerosis (MS). ${ }^{49}$ They were treated with methylprednisone, and after one month, the diplopia resolved.

\section{Discussion}

In this large-scale analysis of SPG4 from CanHSP, we report novel SPAST mutations, the possibility of a founder mutations in the French-Canadian population, novel characteristics of mutations occurring in Arg499, and potential biallelic inheritance. We also report patients with rare or novel clinical manifestations, and co-occurrence of SPG4 and MS. 
medRxiv preprint doi: https://doi.org/10.1101/2021.07.20.21259482; this version posted July 20, 2021. The copyright holder for this preprint (which was not certified by peer review) is the author/funder, who has granted medRxiv a license to display the preprint in perpetuity.

It is made available under a CC-BY 4.0 International license .

Using in silico analysis, we predict that the novel mutations reported in this study cause a loss-of-function of spastin, either by substantially shortening the protein, affecting its ATPase activity, or disturbing the formation of a ternary and quaternary structure necessary for catalysis. Spastin, a microtubule-cleaving enzyme involved in the cytoskeletal rearrangement, ${ }^{50-52}$ also has a role in intracellular trafficking, cytokinesis regulation and resealing of nuclear membrane. ${ }^{53-55}$ In neurons, it is involved in the regeneration of axons and axonal transport. ${ }^{51,56-58}$ Mutations in SPAST could result in a disruption of normal organelle trafficking and distribution, and thus micro-organelle accumulation in axons and swelling of axons ${ }^{59-63}$ which could result in HSP phenotype. We looked further into the three patients identified as sporadic and found out that all carried de novo mutations. Consistent with previous reports of more severe manifestations in patients with de novo mutations, ${ }^{64}$ all patients showed a severe form of the disease. However, it is important to note that the mutation in two of the de novo patients (Arg499His), which is also carried by $33 \%$ of de novo patients, ${ }^{64}$ is associated with a younger AAO, and infantile-onset ascending spastic paraplegia (IAHSP); regardless of the mode of inheritance. ${ }^{65,}{ }^{66}$ Patients harboring this mutation in our cohort did not show all criteria to be diagnosed as IAHSP (spastic paraplegia progressing to tetraplegia, ocular gaze paralysis, pseudobulbar palsy ${ }^{67}$ ), however, they showed a higher probability of suffering from upper extremity weakness, dysarthria, speech and motor delay, learning disabilities and cognitive delay. It has been suggested that amino acid 499 is located in one of the highly conserved regions of the SPAST gene, ${ }^{18}$ and mutations that occur in this region could have a significant effect on the hydrophobicity of the protein and its ability to sever microtubules. ${ }^{45}$

The mutation in our homozygous patient has been reported previously in a heterozygous patient; ${ }^{68}$ however, the presence of an additional mutation or CNVs could not have been 
medRxiv preprint doi: https://doi.org/10.1101/2021.07.20.21259482; this version posted July 20, 2021. The copyright holder for this preprint (which was not certified by peer review) is the author/funder, who has granted medRxiv a license to display the preprint in perpetuity.

It is made available under a CC-BY 4.0 International license.

determined in that study, as only SPAST had been sequenced. Our patient with the homozygous mutation SPAST p.(Tyr51Ter) showed a severe form of the disease. Previously, there have been two reports of homozygous variants in SPAST. One, with the nonsense mutation p.(Ser545Ter), which also reports a complex and severe form of the disease, ${ }^{69}$ and another, with the mutation p.(Leu534Pro), who showed a pure spastic paraparesis at the age of $39 .^{70}$ The patient from our cohort and the previously reported patient with p.(Ser545Ter) presented with a more severe form of the disease, probably because they carried nonsense mutations, while the latter patient had a missense mutation. Furthermore, in the latter study, the parents of the proband were asymptomatic carriers of the mutation.

The mode of inheritance observed in the patient with homozygous mutation and the family carrying the potential modifier mutation SPAST p.(Ser44Leu), may be explained by incomplete penetrance and/or anticipation ${ }^{71-73}$ rather than biallelic inheritance, which could be considered in prenatal diagnosis and genetic counselling. The synonymous mutation SPAST p.(Lys414Lys) we report in three patients has been previously reported to underlie the disease, and minigene assay suggested that this variant leads to an aberrant splicing effect. ${ }^{48}$ Although we did not find other synonymous SPAST mutations in additional HSP patients, it is important to not exclude synonymous variants when analyzing HSP specifically and other diseases in general.

The AAO distribution in our cohort followed the same trend as previously reported, ${ }^{1,68}$ however, our results did not replicate previous findings which suggested that the underlying mutation and the patient sex can modify the disease, and that patients with later onset of the disease can have faster progression. ${ }^{1,24}$ In our data, we did not find an association between mutation type, sex, or late onset, with the disease course. Table 3 compares the frequency of symptoms not attributable to pure form of the disease in our cohort with previous studies. As 
shown, we report deafness in SPG4 for the first time. The co-occurrence of SPG4 and MS has been reported before; ${ }^{74,75}$ however, the results of studies assessing an association between HSPrelated mutations and MS are controversial ${ }^{76,77}$ and further studies are required to verify such a relation.

Our study has several limitations. For instance, in spite of being one of the largest HSP cohorts, the number of SPG4 patients was limited, especially for a genotype-phenotype correlation study. Furthermore, the families interested in participating in this study were probably those who had remained undiagnosed after the primary SPAST testing; therefore, the proportion of SPG4 patients in this study may be underestimated. In addition, clinical signs and symptoms for some of the patients were missing.

In conclusion, we report one of the largest SPG4 cohorts, with 41 different mutations including 6 novel mutations. We suggest that modes of inheritance other than autosomal dominant could be involved in SPG4. Our study sheds light on some rarely reported or unreported aspects of the disease and helps improve genetic counseling and clinical trials conducted on SPG4. Towards this goal, larger efforts and international collaborations are required. 
medRxiv preprint doi: https://doi.org/10.1101/2021.07.20.21259482; this version posted July 20, 2021. The copyright holder for this preprint (which was not certified by peer review) is the author/funder, who has granted medRxiv a license to display the preprint in perpetuity.

It is made available under a CC-BY 4.0 International license .

\section{Acknowledgments}

We thank the patients and their families for participating in this study. This study was funded by CIHR Emerging Team Grant, in collaboration with the Canadian Organization for Rare Disorders (CORD), grant number RN127580 - 260005, and by a CIHR Foundation grant granted to GAR. MAE is funded by the Fonds de Recherche du Québec-Santé (FRQS). GAR holds the Wilder Penfield Chair in Neurosciences. ZGO is supported by the Fonds de recherche du Québec-Santé Chercheur-Boursier award and is a William Dawson Scholar. We thank Patrick Dion, Daniel Rochefort, Helene Catoire, and Vessela Zaharieva for their assistance.

\section{Author's Roles}

P.V.: Research project conception, organization, and execution; statistical analysis design and execution, writing of first draft.

M.A.E.: Research project conception, organization and execution; manuscript review and critique.

S.A., M.F.R., G.Y., M.T., K.M.B., N.D., O.S., and E.L.: Patient recruitment and data collection.

E.L, E.Y, DS, S.V., and J.F.T.: Data analysis.

K.F.: Manuscript preparation.

G.A.R.: Research project conception and organization; manuscript review and critique.

Z.G.O.: Research project conception and organization; statistical analysis design, review and critique; manuscript review and critique.

Financial Disclosures of All Authors (for the Preceding 12 Months) 
medRxiv preprint doi: https://doi.org/10.1101/2021.07.20.21259482; this version posted July 20, 2021. The copyright holder for this preprint (which was not certified by peer review) is the author/funder, who has granted medRxiv a license to display the preprint in perpetuity.

It is made available under a CC-BY 4.0 International license.

M.A.E. received a doctoral award from Fonds de la recherche en santé du Quebec (FRQS). O.S. has received non- related grants - Abbvie, Roche, WaveLifeSciences, and Vaccinex and honoraria - UpToDate and Springer. J.F.T. is a paid consultant and member of the scientific advisory board for Mitokinin Inc. He also received a grant from the Agora Open Science Trust (Grant Number: AOST-M4ND-001). He contributed to three inventions; Report of invention, McGill University Online Disclosure, Track code D2019-0117, Title: The small molecule PRT062607 targets PINK1; Report of invention, McGill University Online Disclosure, Track code D2020-0190, Title: Indole-2-carboxylic acid derivatives bind to Parkin; Report of invention, McGill University Online Disclosure, Track code D2021-0004, Title: Method for the expression and purification of Taq DNA polymerase. G.A.R. received grants from the following agencies and organizations: CIHR Foundation Scheme, Genome Quebec, ERANET PerMed/FRSQ, ALS Canada-Brain Canada, ALS Canada, Radala Foundation, CQDM, ALS Canada-Brain Canada, Brain Canada. Z.G.O. is supported by the Fonds de recherche du QuebecSante (FRQS) Chercheurs-boursiers award, and is a Parkinson's Disease Canada New Investigator awardee. He received consultancy fees from Ono Therapeutics, Handl Therapeutics, Neuron23, Lysosomal Therapeutics Inc., Bial Biotech Inc., Deerfield, Lighthouse, and Idorsia, all unrelated to the current study. All other authors report nothing to disclose. 
medRxiv preprint doi: https://doi.org/10.1101/2021.07.20.21259482; this version posted July 20, 2021. The copyright holder for this preprint (which was not certified by peer review) is the author/funder, who has granted medRxiv a license to display the preprint in perpetuity.

\section{References}

1. Parodi L, Fenu S, Barbier M, et al. Spastic paraplegia due to SPAST mutations is modified by the underlying mutation and sex. Brain 2018;141(12):3331-3342.

2. Giudice TL, Lombardi F, Santorelli FM, Kawarai T, Orlacchio A. Hereditary spastic paraplegia: clinical-genetic characteristics and evolving molecular mechanisms. Experimental neurology 2014;261:518-539.

3. Solowska JM, Baas PW. Hereditary spastic paraplegia SPG4: what is known and not known about the disease. Brain 2015;138(9):2471-2484.

4. Estiar MA, Yu E, Salem IH, et al. Evidence for non-Mendelian inheritance in spastic paraplegia 7. medRxiv 2020.

5. Ruano L, Melo C, Silva MC, Coutinho P. The global epidemiology of hereditary ataxia and spastic paraplegia: a systematic review of prevalence studies. Neuroepidemiology 2014;42(3):174-183.

6. Skre H. Hereditary spastic paraplegia in Western Norway. Clinical genetics 1974;6(3):165-183.

7. McMonagle P, Webb S, Hutchinson M. The prevalence of "pure" autosomal dominant hereditary spastic paraparesis in the island of Ireland. Journal of Neurology, Neurosurgery \& Psychiatry 2002;72(1):43-46.

8. Polo J, Calleja J, Combarros O, Berciano J. Hereditary ataxias and paraplegias in Cantabria, Spain: an epidemiological and clinical study. Brain 1991;114(2):855-866.

9. Harding A. Hereditary" pure" spastic paraplegia: a clinical and genetic study of 22 families. Journal of Neurology, Neurosurgery \& Psychiatry 1981;44(10):871-883.

10. Schüle R, Wiethoff S, Martus P, et al. Hereditary spastic paraplegia: clinicogenetic lessons from 608 patients. Annals of neurology 2016;79(4):646-658.

11. Koh K, Ishiura H, Tsuji S, Takiyama Y. JASPAC: Japan spastic paraplegia research consortium. Brain sciences 2018;8(8):153.

12. Blackstone C. Hereditary spastic paraplegia. Handbook of clinical neurology 2018;148:633-652.

13. Parodi L, Fenu S, Stevanin G, Durr A. Hereditary spastic paraplegia: more than an upper motor neuron disease. Revue neurologique 2017;173(5):352-360.

14. Martinuzzi A, Montanaro D, Vavla M, et al. Clinical and paraclinical indicators of motor system impairment in hereditary spastic paraplegia: a pilot study. PLoS One 2016;11(4):e0153283.

15. Klebe S, Stevanin G, Depienne C. Clinical and genetic heterogeneity in hereditary spastic paraplegias: from SPG1 to SPG72 and still counting. Revue neurologique 2015;171(6-7):505530.

16. Hazan J, Fonknechten N, Mavel D, et al. Spastin, a new AAA protein, is altered in the most frequent form of autosomal dominant spastic paraplegia. Nature genetics 1999;23(3):296303.

17. Depienne C, Stevanin G, Brice A, Durr A. Hereditary spastic paraplegias: an update. Current opinion in neurology 2007;20(6):674-680.

18. Errico A, Ballabio A, Rugarli EI. Spastin, the protein mutated in autosomal dominant hereditary spastic paraplegia, is involved in microtubule dynamics. Human molecular genetics 2002;11(2):153-163. 
medRxiv preprint doi: https://doi.org/10.1101/2021.07.20.21259482; this version posted July 20, 2021. The copyright holder for this preprint (which was not certified by peer review) is the author/funder, who has granted medRxiv a license to display the preprint in perpetuity. It is made available under a CC-BY 4.0 International license .

19. Vemu A, Szczesna E, Zehr EA, et al. Severing enzymes amplify microtubule arrays through lattice GTP-tubulin incorporation. Science 2018;361(6404).

20. Salinas S, Carazo $\square$ Salas RE, Proukakis C, Schiavo G, Warner TT. Spastin and microtubules: Functions in health and disease. Journal of neuroscience research 2007;85(12):2778-2782.

21. Han H, Schubert HL, McCullough J, et al. Structure of spastin bound to a glutamate-rich peptide implies a hand-over-hand mechanism of substrate translocation. Journal of Biological Chemistry 2020;295(2):435-443.

22. Zehr E, Szyk A, Piszczek G, Szczesna E, Zuo X, Roll-Mecak A. Katanin spiral and ring structures shed light on power stroke for microtubule severing. Nature structural \& molecular biology 2017;24(9):717.

23. Sandate CR, Szyk A, Zehr EA, Lander GC, Roll-Mecak A. An allosteric network in spastin couples multiple activities required for microtubule severing. Nature structural \& molecular biology 2019;26(8):671-678.

24. Fonknechten N, Mavel D, Byrne P, et al. Spectrum of SPG4 mutations in autosomal dominant spastic paraplegia. Human molecular genetics 2000;9(4):637-644.

25. Lindsey J, Lusher M, McDermott C, et al. Mutation analysis of the spastin gene (SPG4) in patients with hereditary spastic paraparesis. Journal of medical genetics 2000;37(10):759-765. 26. Shoukier M, Neesen J, Sauter SM, et al. Expansion of mutation spectrum, determination of mutation cluster regions and predictive structural classification of SPAST mutations in hereditary spastic paraplegia. European journal of human genetics 2009;17(2):187-194.

27. Depienne C, Fedirko E, Forlani S, et al. Exon deletions of SPG4 are a frequent cause of hereditary spastic paraplegia. Journal of medical genetics 2007;44(4):281-284.

28. Beetz C, Nygren A, Schickel J, et al. High frequency of partial SPAST deletions in autosomal dominant hereditary spastic paraplegia. Neurology 2006;67(11):1926-1930.

29. Fink JK. Hereditary spastic paraplegia: clinico-pathologic features and emerging molecular mechanisms. Acta neuropathologica 2013;126(3):307-328.

30. de Souza PVS, de Rezende Pinto WBV, de Rezende Batistella GN, Bortholin T, Oliveira ASB. Hereditary spastic paraplegia: clinical and genetic hallmarks. The Cerebellum 2017;16(2):525-551.

31. Chrestian N, Dupré N, Gan-Or Z, et al. Clinical and genetic study of hereditary spastic paraplegia in Canada. Neurology Genetics 2017;3(1).

32. Schüle R, Holland-Letz T, Klimpe S, et al. The Spastic Paraplegia Rating Scale (SPRS): a reliable and valid measure of disease severity. Neurology 2006;67(3):430-434.

33. Adry RARdC, Lins CC, Kruschewsky RdA, Castro Filho BG. Comparison between the spastic paraplegia rating scale, Kurtzke scale, and Osame scale in the tropical spastic paraparesis/myelopathy associated with HTLV. Revista da Sociedade Brasileira de Medicina Tropical 2012;45(3):309-312.

34. Miller S, Dykes D, Polesky H. A simple salting out procedure for extracting DNA from human nucleated cells. Nucleic acids research 1988;16(3):1215.

35. Li H, Durbin R. Fast and accurate short read alignment with Burrows-Wheeler transform. bioinformatics 2009;25(14):1754-1760.

36. McKenna A, Hanna M, Banks E, et al. The Genome Analysis Toolkit: a MapReduce framework for analyzing next-generation DNA sequencing data. Genome research 2010;20(9):1297-1303. 
medRxiv preprint doi: https://doi.org/10.1101/2021.07.20.21259482; this version posted July 20, 2021. The copyright holder for this preprint (which was not certified by peer review) is the author/funder, who has granted medRxiv a license to display the preprint in perpetuity. It is made available under a CC-BY 4.0 International license .

37. Wang K, Li M, Hakonarson H. ANNOVAR: functional annotation of genetic variants from high-throughput sequencing data. Nucleic acids research 2010;38(16):e164-e164.

38. Karczewski KJ, Francioli LC, Tiao G, et al. The mutational constraint spectrum quantified from variation in 141,456 humans. Nature 2020;581(7809):434-443.

39. Kopanos C, Tsiolkas V, Kouris A, et al. VarSome: the human genomic variant search engine. Bioinformatics 2019;35(11):1978.

40. Plagnol V, Curtis J, Epstein M, et al. A robust model for read count data in exome sequencing experiments and implications for copy number variant calling. Bioinformatics 2012;28(21):2747-2754.

41. Mitchell AL, Attwood TK, Babbitt PC, et al. InterPro in 2019: improving coverage, classification and access to protein sequence annotations. Nucleic acids research 2019;47(D1):D351-D360.

42. Rodrigues CH, Pires DE, Ascher DB. DynaMut: predicting the impact of mutations on protein conformation, flexibility and stability. Nucleic acids research 2018;46(W1):W350-W355. 43. Evans KJ, Gomes ER, Reisenweber SM, Gundersen GG, Lauring BP. Linking axonal degeneration to microtubule remodeling by Spastin-mediated microtubule severing. The Journal of cell biology 2005;168(4):599-606.

44. Meijer IA, Dupré N, Brais B, et al. SPG4 founder effect in French Canadians with hereditary spastic paraplegia. Canadian journal of neurological sciences 2007;34(2):211-214. 45. Gillespie MK, Humphreys P, McMillan HJ, Boycott KM. Association of early-onset spasticity and risk for cognitive impairment with mutations at amino acid 499 in SPAST. Journal of child neurology 2018;33(5):329-332.

46. McDermott C, Burness C, Kirby J, et al. Clinical features of hereditary spastic paraplegia due to spastin mutation. Neurology 2006;67(1):45-51.

47. Svenson IK, Kloos MT, Gaskell PC, et al. Intragenic modifiers of hereditary spastic paraplegia due to spastin gene mutations. Neurogenetics 2004;5(3):157-164.

48. Svenson IK, Ashley-Koch AE, Gaskell PC, et al. Identification and expression analysis of spastin gene mutations in hereditary spastic paraplegia. The American Journal of Human Genetics 2001;68(5):1077-1085.

49. Sorensen PS, Sellebjerg F, Hartung H-P, Montalban X, Comi G, Tintoré M. The apparently milder course of multiple sclerosis: changes in the diagnostic criteria, therapy and natural history. Brain 2020;143(9):2637-2652.

50. Lumb JH, Connell JW, Allison R, Reid E. The AAA ATPase spastin links microtubule severing to membrane modelling. Biochimica et Biophysica Acta (BBA)-Molecular Cell Research 2012;1823(1):192-197.

51. Sardina F, Pisciottani A, Ferrara M, et al. Spastin recovery in hereditary spastic paraplegia by preventing neddylation-dependent degradation. Life science alliance 2020;3(12).

52. Connell JW, Allison RJ, Rodger CE, Pearson G, Zlamalova E, Reid E. ESCRT-IIIassociated proteins and spastin inhibit protrudin-dependent polarised membrane traffic. Cellular and Molecular Life Sciences 2020;77(13):2641-2658.

53. Connell JW, Lindon C, Luzio JP, Reid E. Spastin couples microtubule severing to membrane traffic in completion of cytokinesis and secretion. Traffic 2009;10(1):42-56.

54. Allison R, Lumb JH, Fassier C, et al. An ESCRT-spastin interaction promotes fission of recycling tubules from the endosome. Journal of Cell Biology 2013;202(3):527-543.

55. Vietri M, Schink KO, Campsteijn C, et al. Spastin and ESCRT-III coordinate mitotic spindle disassembly and nuclear envelope sealing. Nature 2015;522(7555):231-235. 
medRxiv preprint doi: https://doi.org/10.1101/2021.07.20.21259482; this version posted July 20, 2021. The copyright holder for this preprint (which was not certified by peer review) is the author/funder, who has granted medRxiv a license to display the preprint in perpetuity. It is made available under a CC-BY 4.0 International license .

56. Trotta N, Orso G, Rossetto MG, Daga A, Broadie K. The hereditary spastic paraplegia gene, spastin, regulates microtubule stability to modulate synaptic structure and function. Current biology 2004;14(13):1135-1147.

57. Riano E, Martignoni M, Mancuso G, et al. Pleiotropic effects of spastin on neurite growth depending on expression levels. Journal of neurochemistry 2009;108(5):1277-1288.

58. Stone MC, Rao K, Gheres KW, et al. Normal spastin gene dosage is specifically required for axon regeneration. Cell reports 2012;2(5):1340-1350.

59. Tarrade A, Fassier C, Courageot S, et al. A mutation of spastin is responsible for swellings and impairment of transport in a region of axon characterized by changes in microtubule composition. Human molecular genetics 2006;15(24):3544-3558.

60. Kasher PR, De Vos KJ, Wharton SB, et al. Direct evidence for axonal transport defects in a novel mouse model of mutant spastin $\square$ induced hereditary spastic paraplegia (HSP) and human HSP patients. Journal of neurochemistry 2009;110(1):34-44.

61. Denton KR, Lei L, Grenier J, Rodionov V, Blackstone C, Li XJ. Loss of spastin function results in disease $\square$ specific axonal defects in human pluripotent stem cell $\square$ based models of hereditary spastic paraplegia. Stem cells 2014;32(2):414-423.

62. Havlicek S, Kohl Z, Mishra HK, et al. Gene dosage-dependent rescue of HSP neurite defects in SPG4 patients' neurons. Human molecular genetics 2014;23(10):2527-2541.

63. TARRADE A, Peris L, Courageot S, et al. Microtubule-targeting drugs rescue axonal swellings in cortical neurons from spastin knockout mice. Disease Models \& Mechanisms 1 (6), 72-83(2013) 2013.

64. Schieving JH, de Bot ST, van de Pol LA, et al. De novo SPAST mutations may cause a complex SPG4 phenotype. Brain 2019;142(7):e31-e31.

65. Souza PVSd, Bortholin T, Naylor FGM, Pinto WBVdR, Oliveira ASB. Infantile-onset ascending spastic paraplegia phenotype associated with SPAST mutation. Journal of the neurological sciences 2016.

66. Ogasawara M, Saito T, Koshimizu E, Akasaka N, Sasaki M. A p. Arg499His Mutation in SPAST Is Associated with Infantile Onset Ascending Spastic Paralysis Complicated with Dysarthria and Anarthria. Neuropediatrics 2019;50(06):391-394.

67. Lesca G, Eymard-Pierre E, Santorelli F, et al. Infantile ascending hereditary spastic paralysis (IAHSP): clinical features in 11 families. Neurology 2003;60(4):674-682.

68. de Bot ST, van den Elzen RT, Mensenkamp A, et al. Hereditary spastic paraplegia due to SPAST mutations in 151 Dutch patients: new clinical aspects and 27 novel mutations. Journal of Neurology, Neurosurgery \& Psychiatry 2010;81(10):1073-1078.

69. Cruz-Camino H, Vázquez-Cantú M, Vázquez-Cantú DL, et al. Clinical Characterization of 2 Siblings with a Homozygous SPAST Variant. The American Journal of Case Reports 2020;21:e919463-919461.

70. de Bot ST, Van Den Elzen R, Mensenkamp A, et al. Hereditary spastic paraplegia due to SPAST mutations in 151 Dutch patients: new clinical aspects and 27 novel mutations. Journal of Neurology, Neurosurgery \& Psychiatry 2010;81(10):1073-1078.

71. Bürger J, Metzke H, Paternotte C, Schilling F, Hazan J, Reis A. Autosomal dominant spastic paraplegia with anticipation maps to a 4-cM interval on chromosome 2p21-p24 in a large German family. Human genetics 1996;98(3):371-375.

72. Reddy PL, Seltzer WK, Grewal RP. Possible anticipation in hereditary spastic paraplegia type 4 (SPG4). Canadian Journal of Neurological Sciences 2007;34(2):208-210. 
medRxiv preprint doi: https://doi.org/10.1101/2021.07.20.21259482; this version posted July 20, 2021. The copyright holder for this preprint (which was not certified by peer review) is the author/funder, who has granted medRxiv a license to display the preprint in perpetuity.

It is made available under a CC-BY 4.0 International license .

73. Kawarai T, Montecchiani C, Miyamoto R, et al. Spastic paraplegia type 4: A novel SPAST splice site donor mutation and expansion of the phenotype variability. Journal of the neurological sciences 2017;380:92-97.

74. Boucher JJ, Counihan TJ. Co-incident primary progressive multiple sclerosis and hereditary spastic paraplegia (SPG4)-a case report. Multiple Sclerosis and Related Disorders 2020;44:102375.

75. Mead S, Proukakis C, Wood N, Crosby A, Plant G, Warner T. A large family with hereditary spastic paraparesis due to a frame shift mutation of the spastin (SPG4) gene: association with multiple sclerosis in two affected siblings and epilepsy in other affected family members. Journal of Neurology, Neurosurgery \& Psychiatry 2001;71(6):788-791.

76. Jia X, Madireddy L, Caillier S, et al. Genome sequencing uncovers phenocopies in primary progressive multiple sclerosis. Annals of neurology 2018;84(1):51-63.

77. DeLuca G, Ramagopalan SV, Cader M, et al. The role of hereditary spastic paraplegia related genes in multiple sclerosis. Journal of neurology 2007;254(9):1221-1226.

78. Murphy S, Gorman G, Beetz C, et al. Dementia in SPG4 hereditary spastic paraplegia: clinical, genetic, and neuropathologic evidence. Neurology 2009;73(5):378-384.

79. Ribaï P, Depienne C, Fedirko E, et al. Mental deficiency in three families with SPG4 spastic paraplegia. European journal of human genetics 2008;16(1):97-104.

80. Nielsen J, Johnsen B, Koefoed P, et al. Hereditary spastic paraplegia with cerebellar ataxia: a complex phenotype associated with a new SPG4 gene mutation. European journal of neurology 2004;11(12):817-824.

81. Tallaksen CM, Guichart-Gomez E, Verpillat P, et al. Subtle cognitive impairment but no dementia in patients with spastin mutations. Archives of neurology 2003;60(8):1113-1118.

82. Chamard L, Ferreira S, Pijoff A, Silvestre M, Berger E, Magnin E. Cognitive impairment involving social cognition in SPG4 hereditary spastic paraplegia. Behavioural neurology $2016 ; 2016$.

83. Orlacchio A, Kawarai T, Totaro A, et al. Hereditary spastic paraplegia: clinical genetic study of 15 families. Archives of Neurology 2004;61(6):849-855.

84. Orlacchio A, Gaudiello F, Totaro A, et al. A new SPG4 mutation in a variant form of spastic paraplegia with congenital arachnoid cysts. Neurology 2004;62(10):1875-1878.

85. Guthrie G, Pfeffer G, Bailie M, et al. The neurological and ophthalmological manifestations of SPG4-related hereditary spastic paraplegia. Journal of neurology 2013;260(3):906-909.

86. Kumar KR, Sue CM, Burke D, Ng K. Peripheral neuropathy in hereditary spastic paraplegia due to spastin (SPG4) mutation-a neurophysiological study using excitability techniques. Clinical neurophysiology 2012;123(7):1454-1459. 
Tables

Table 1. Frequency of signs and symptoms among different categories of gender, mutation type and protein domain.

\begin{tabular}{|c|c|c|c|c|c|c|c|c|c|c|c|c|c|}
\hline \multirow{2}{*}{$\begin{array}{l}\text { Clinical } \\
\text { presentation }\end{array}$} & \multirow[t]{2}{*}{ Frequency } & \multicolumn{3}{|c|}{ Gender } & \multicolumn{3}{|c|}{ Type of mutation } & \multicolumn{6}{|c|}{ Protein domain (missense mutations) } \\
\hline & & $\begin{array}{l}\text { Male } \\
(n=72, \\
45.9 \%)\end{array}$ & $\begin{array}{l}\text { Female } \\
(n=85, \\
54.1 \%)\end{array}$ & $\begin{array}{l}\mathbf{P} \\
\text { value }\end{array}$ & $\begin{array}{l}\mathrm{LoF} \\
(\mathrm{n}=21 / 41)\end{array}$ & $\begin{array}{l}\text { Missense } \\
(n=20 / 41)\end{array}$ & $\begin{array}{l}\mathbf{P} \\
\text { value }\end{array}$ & MIT $^{\mathbf{a}}$ & AAA_ATPase ${ }^{\mathrm{b}}$ & AAA_lid_3 ${ }^{\text {c }}$ & Vps4_C ${ }^{d}$ & $\begin{array}{l}\text { Other } \\
\text { domains }\end{array}$ & $\begin{array}{l}P \\
\text { value }\end{array}$ \\
\hline $\begin{array}{l}\text { Mean Age at } \\
\text { onset } \pm \text { SD }\end{array}$ & - & $\begin{array}{l}25.9 \pm \\
19.6\end{array}$ & $19 \pm 20$ & .040 & $24 \pm 20$ & $\begin{array}{l}27.4 \pm \\
20.2\end{array}$ & .465 & 38 & $22.9 \pm 19.2$ & $32.5 \pm 21.7$ & $29.3 \pm 23.3$ & $30.5 \pm 19.1$ & .626 \\
\hline $\begin{array}{l}\text { Mean SPRS } \\
\text { score } \pm S D\end{array}$ & - & $\begin{array}{l}23.1 \pm \\
12.5\end{array}$ & $\begin{array}{l}22 \pm \\
14.7\end{array}$ & .853 & $22 \pm 8.7$ & $\begin{array}{l}22.8 \pm \\
15.6\end{array}$ & .696 & 28 & $20.1 \pm 14.3$ & $6.0 \pm 2.8$ & 3 & $34.6 \pm 6.6$ & .066 \\
\hline $\begin{array}{l}\text { Lower } \\
\text { extremity } \\
\text { weakness }\end{array}$ & $\begin{array}{l}53 / 102 \\
(52 \%)\end{array}$ & $\begin{array}{l}25 / 44 \\
(56.8 \%)\end{array}$ & $\begin{array}{l}28 / 58 \\
(48.3 \%)\end{array}$ & .392 & $\begin{array}{l}10 / 24 \\
(41.6 \%)\end{array}$ & $\begin{array}{l}35 / 50 \\
(70 \%)\end{array}$ & .019 & - & $\begin{array}{l}24 / 32 \\
(75 \%)\end{array}$ & $\begin{array}{l}3 / 10 \\
(30 \%)\end{array}$ & $\begin{array}{l}1 / 1 \\
(100 \%)\end{array}$ & $\begin{array}{l}7 / 7 \\
(100 \%)\end{array}$ & .010 \\
\hline $\begin{array}{l}\text { Lower } \\
\text { extremity } \\
\text { spasticity }\end{array}$ & $\begin{array}{l}92 / 109 \\
(84.4 \%)\end{array}$ & $\begin{array}{l}44 / 48 \\
(91.7 \%)\end{array}$ & $\begin{array}{l}48 / 61 \\
(78.7 \%)\end{array}$ & .064 & $\begin{array}{l}25 / 28 \\
(89.3 \%)\end{array}$ & $\begin{array}{l}45 / 49 \\
(91.8 \%)\end{array}$ & .708 & - & $\begin{array}{l}32 / 32 \\
(100 \%)\end{array}$ & $\begin{array}{l}7 / 10 \\
(70 \%)\end{array}$ & - & $\begin{array}{l}6 / 7 \\
(85.7 \%)\end{array}$ & .008 \\
\hline $\begin{array}{l}\text { Lower } \\
\text { extremity } \\
\text { hyperreflexia }\end{array}$ & $\begin{array}{l}102 / 111 \\
(91.9 \%)\end{array}$ & $\begin{array}{l}46 / 49 \\
(93.9 \%)\end{array}$ & $\begin{array}{l}56 / 62 \\
(90.3 \%)\end{array}$ & .496 & $\begin{array}{l}25 / 25 \\
(100 \%)\end{array}$ & $\begin{array}{l}51 / 53 \\
(96.2 \%)\end{array}$ & .325 & - & $\begin{array}{l}32 / 33 \\
(97 \%)\end{array}$ & $\begin{array}{l}13 / 13 \\
(100 \%)\end{array}$ & - & $\begin{array}{l}6 / 7 \\
(85.7 \%)\end{array}$ & .261 \\
\hline $\begin{array}{l}\text { Extensor } \\
\text { plantar } \\
\text { response }\end{array}$ & $\begin{array}{l}82 / 105 \\
(78.1 \%)\end{array}$ & $\begin{array}{l}38 / 44 \\
(86.4 \%)\end{array}$ & $\begin{array}{l}44 / 61 \\
(72.1 \%)\end{array}$ & .082 & $\begin{array}{l}19 / 24 \\
(79.2 \%)\end{array}$ & $\begin{array}{l}46 / 50 \\
(92 \%)\end{array}$ & .114 & - & $\begin{array}{l}30 / 31 \\
(96.8 \%)\end{array}$ & $\begin{array}{l}10 / 12 \\
(83.3 \%)\end{array}$ & - & $\begin{array}{l}6 / 7 \\
(85.7 \%)\end{array}$ & .278 \\
\hline $\begin{array}{l}\text { Abnormal } \\
\text { bladder } \\
\text { function }\end{array}$ & $\begin{array}{l}52 / 100 \\
(52 \%)\end{array}$ & $\begin{array}{l}25 / 43 \\
(58.1 \%)\end{array}$ & $\begin{array}{l}27 / 57 \\
(47.4 \%)\end{array}$ & .286 & $\begin{array}{l}15 / 22 \\
(68.2 \%)\end{array}$ & $\begin{array}{l}28 / 51 \\
(54.9 \%)\end{array}$ & .290 & - & $\begin{array}{l}15 / 32 \\
(46.9 \%)\end{array}$ & $\begin{array}{l}6 / 11 \\
(54.5 \%)\end{array}$ & $\begin{array}{l}1 / 1 \\
(100 \%)\end{array}$ & $\begin{array}{l}6 / 7 \\
(85.7 \%)\end{array}$ & .227 \\
\hline Ankle clonus & $\begin{array}{l}59 / 97 \\
(60.8 \%)\end{array}$ & $\begin{array}{l}25 / 40 \\
(62.5 \%)\end{array}$ & $\begin{array}{l}34 / 57 \\
(59.6 \%)\end{array}$ & .777 & $\begin{array}{l}14 / 22 \\
(63.6 \%)\end{array}$ & $\begin{array}{l}34 / 47 \\
(72.3 \%)\end{array}$ & .464 & - & $\begin{array}{l}19 / 28 \\
(67.9 \%)\end{array}$ & $\begin{array}{l}11 / 12 \\
(91.7 \%)\end{array}$ & - & $\begin{array}{l}4 / 7 \\
(57.1 \%)\end{array}$ & .189 \\
\hline Motor delay & $\begin{array}{l}9 / 50 \\
(18 \%)\end{array}$ & $\begin{array}{l}3 / 24 \\
(12.5 \%)\end{array}$ & $\begin{array}{l}6 / 26 \\
(23.1 \%)\end{array}$ & .331 & $\begin{array}{l}0 / 10 \\
(0 \%)\end{array}$ & $\begin{array}{l}7 / 34 \\
(20.6 \%)\end{array}$ & .118 & - & $\begin{array}{l}6 / 22 \\
(27.3 \%)\end{array}$ & $\begin{array}{l}0 / 6 \\
(0 \%)\end{array}$ & $\begin{array}{l}0 / 1 \\
(0 \%)\end{array}$ & $\begin{array}{l}1 / 5 \\
(20 \%)\end{array}$ & .490 \\
\hline $\begin{array}{l}\text { Speech delay } \\
\text { or } \\
\text { abnormality }\end{array}$ & $\begin{array}{l}8 / 47 \\
(17 \%)\end{array}$ & $\begin{array}{l}3 / 24 \\
(12.5 \%)\end{array}$ & $\begin{array}{l}5 / 23 \\
(21.7 \%)\end{array}$ & .400 & $\begin{array}{l}0 / 11 \\
(0 \%)\end{array}$ & $\begin{array}{l}8 / 31 \\
(25.8 \%)\end{array}$ & .061 & - & $\begin{array}{l}6 / 20 \\
(30 \%)\end{array}$ & $\begin{array}{l}1 / 6 \\
(16.7 \%)\end{array}$ & $\begin{array}{l}0 / 1 \\
(0 \%)\end{array}$ & $\begin{array}{l}1 / 4 \\
(25 \%)\end{array}$ & .851 \\
\hline $\begin{array}{l}\text { Learning } \\
\text { disability }\end{array}$ & $\begin{array}{l}10 / 51 \\
(19.6 \%)\end{array}$ & $\begin{array}{l}3 / 25(12 \\
\%)\end{array}$ & $\begin{array}{l}7 / 26 \\
(26.9 \%)\end{array}$ & .180 & $\begin{array}{l}0 / 11 \\
(0 \%)\end{array}$ & $\begin{array}{l}8 / 34 \\
(23.5 \%)\end{array}$ & .076 & - & $\begin{array}{l}7 / 22 \\
(31.8 \%)\end{array}$ & $0 / 6$ & $\begin{array}{l}0 / 1 \\
(0 \%)\end{array}$ & $\begin{array}{l}1 / 5 \\
(20 \%)\end{array}$ & .387 \\
\hline $\begin{array}{l}\text { Progressive } \\
\text { cognitive } \\
\text { deficiency }\end{array}$ & $\begin{array}{l}6 / 73 \\
(8.2 \%)\end{array}$ & $\begin{array}{l}5 / 36 \\
(13.9 \%)\end{array}$ & $\begin{array}{l}1 / 37 \\
(2.7 \%)\end{array}$ & .082 & $\begin{array}{l}1 / 19 \\
(5.3 \%)\end{array}$ & $\begin{array}{l}3 / 42 \\
(7.1 \%)\end{array}$ & .784 & - & $\begin{array}{l}3 / 28 \\
(10.7 \%)\end{array}$ & $\begin{array}{l}0 / 6 \\
(0 \%)\end{array}$ & $\begin{array}{l}0 / 1 \\
(0 \%)\end{array}$ & $\begin{array}{l}0 / 7 \\
(0 \%)\end{array}$ & .656 \\
\hline $\begin{array}{l}\text { Retinopathy } \\
\text { or optic }\end{array}$ & $\begin{array}{l}1 / 71 \\
(1.4 \%)\end{array}$ & $\begin{array}{l}0 / 34 \\
(0 \%)\end{array}$ & $\begin{array}{l}1 / 38 \\
(2.6 \%)\end{array}$ & .348 & - & - & - & - & - & - & - & - & - \\
\hline
\end{tabular}




\begin{tabular}{|c|c|c|c|c|c|c|c|c|c|c|c|c|c|}
\hline atrophy & & & & & & & & & & & & & \\
\hline $\begin{array}{l}\text { Ocular } \\
\text { movement } \\
\text { abnormalities }\end{array}$ & $\begin{array}{l}1 / 72 \\
(1.4 \%)\end{array}$ & $\begin{array}{l}0 / 33 \\
(0 \%)\end{array}$ & $\begin{array}{l}1 / 38 \\
(2.6 \%)\end{array}$ & .341 & $\begin{array}{l}1 / 19 \\
(5.3 \%)\end{array}$ & $\begin{array}{l}0 / 41 \\
(0 \%)\end{array}$ & .139 & - & - & - & - & - & - \\
\hline Deafness & $\begin{array}{l}4 / 71 \\
(5.6 \%)\end{array}$ & $\begin{array}{l}3 / 34 \\
(8.8 \%)\end{array}$ & $\begin{array}{l}1 / 37 \\
(2.7 \%)\end{array}$ & .264 & $\begin{array}{l}0 / 19 \\
(0 \%)\end{array}$ & $\begin{array}{l}4 / 41 \\
(9.8 \%)\end{array}$ & .159 & - & $\begin{array}{l}2 / 27 \\
(7.4 \%)\end{array}$ & $\begin{array}{l}0 / 6 \\
(0 \%)\end{array}$ & $\begin{array}{l}1 / 1 \\
(100 \%)\end{array}$ & $\begin{array}{l}1 / 7 \\
(14.3 \%)\end{array}$ & .017 \\
\hline $\begin{array}{l}\text { Swallowing } \\
\text { difficulty }\end{array}$ & $\begin{array}{l}4 / 72 \\
(5.6 \%)\end{array}$ & $\begin{array}{l}1 / 34 \\
(2.9 \%)\end{array}$ & $\begin{array}{l}3 / 38 \\
(7.9 \%)\end{array}$ & .360 & $\begin{array}{l}0 / 20 \\
(0 \%)\end{array}$ & $\begin{array}{l}4 / 40 \\
(10 \%)\end{array}$ & .143 & - & $\begin{array}{l}3 / 27 \\
(11.1 \%)\end{array}$ & $\begin{array}{l}0 / 6 \\
(0 \%)\end{array}$ & $\begin{array}{l}0 / 1 \\
(0 \%)\end{array}$ & $\begin{array}{l}1 / 6 \\
(16.7 \%)\end{array}$ & .774 \\
\hline Dysarthria & $\begin{array}{l}12 / 73 \\
(16.4 \%)\end{array}$ & $\begin{array}{l}5 / 35 \\
(14.3 \%)\end{array}$ & $\begin{array}{l}7 / 38 \\
(18.4 \%)\end{array}$ & .634 & $\begin{array}{l}3 / 20 \\
(15 \%)\end{array}$ & $\begin{array}{l}8 / 41 \\
(19.5 \%)\end{array}$ & .667 & - & $\begin{array}{l}6 / 27 \\
(22.2 \%) \\
\end{array}$ & $\begin{array}{l}1 / 6 \\
(16.7 \%)\end{array}$ & $\begin{array}{l}0 / 1 \\
(0 \%)\end{array}$ & $\begin{array}{l}1 / 7 \\
(14.3 \%)\end{array}$ & .914 \\
\hline $\begin{array}{l}\text { Upper } \\
\text { extremity } \\
\text { weakness }\end{array}$ & $\begin{array}{l}5 / 72 \\
(6.9 \%)\end{array}$ & $\begin{array}{l}2 / 34 \\
(5.9 \%)\end{array}$ & $\begin{array}{l}3 / 38 \\
(7.7 \%)\end{array}$ & .737 & $\begin{array}{l}0 / 19 \\
(0 \%)\end{array}$ & $\begin{array}{l}4 / 41 \\
(9.8 \%)\end{array}$ & .159 & - & $\begin{array}{l}3 / 27 \\
(11.1 \%)\end{array}$ & $\begin{array}{l}0 / 6 \\
(0 \%)\end{array}$ & $\begin{array}{l}0 / 1 \\
(0 \%)\end{array}$ & $\begin{array}{l}1 / 7 \\
(14.3 \%)\end{array}$ & .807 \\
\hline $\begin{array}{l}\text { Upper } \\
\text { extremity } \\
\text { hyperreflexia }\end{array}$ & $\begin{array}{l}31 / 77 \\
(40.3 \%)\end{array}$ & $\begin{array}{l}15 / 36 \\
(41.7 \%)\end{array}$ & $\begin{array}{l}16 / 41 \\
(39 \%)\end{array}$ & .814 & $\begin{array}{l}11 / 21 \\
(52.4 \%)\end{array}$ & $\begin{array}{l}15 / 44 \\
(34.1 \%)\end{array}$ & .159 & - & $\begin{array}{l}8 / 27 \\
(29.6 \%)\end{array}$ & $\begin{array}{l}3 / 9 \\
(33.3 \%)\end{array}$ & $\begin{array}{l}1 / 1 \\
(100 \%)\end{array}$ & $\begin{array}{l}3 / 7 \\
(42.9 \%)\end{array}$ & .491 \\
\hline $\begin{array}{l}\text { Sensory } \\
\text { abnormalities }\end{array}$ & $\begin{array}{l}33 / 73 \\
(45.2 \%)\end{array}$ & $\begin{array}{l}15 / 35 \\
(42.9 \%)\end{array}$ & $\begin{array}{l}18 / 38 \\
(47.4 \%)\end{array}$ & 699 & $\begin{array}{l}10 / 21 \\
(47.6 \%)\end{array}$ & $\begin{array}{l}19 / 40 \\
(47.5 \%)\end{array}$ & .993 & - & $\begin{array}{l}12 / 26 \\
(46.2 \%)\end{array}$ & $\begin{array}{l}3 / 6 \\
(50 \%)\end{array}$ & $\begin{array}{l}1 / 1 \\
(100 \%)\end{array}$ & $\begin{array}{l}3 / 7 \\
(42.9 \%)\end{array}$ & .753 \\
\hline $\begin{array}{l}\text { Peripheral } \\
\text { neuropathy }\end{array}$ & $\begin{array}{l}10 / 70 \\
(14.3 \%) \\
\end{array}$ & $\begin{array}{l}4 / 35 \\
(11.4 \%) \\
\end{array}$ & $\begin{array}{l}6 / 35 \\
(17.1 \%) \\
\end{array}$ & .495 & $\begin{array}{l}2 / 20 \\
(10 \%)\end{array}$ & $\begin{array}{l}7 / 39 \\
(17.9 \%) \\
\end{array}$ & .421 & - & $\begin{array}{l}5 / 24 \\
(20.8 \%) \\
\end{array}$ & $\begin{array}{l}1 / 8 \\
(12.5 \%)\end{array}$ & $\begin{array}{l}0 / 1 \\
(0 \%) \\
\end{array}$ & $\begin{array}{l}1 / 6 \\
(16.7 \%) \\
\end{array}$ & .914 \\
\hline Pes cavus & $\begin{array}{l}16 / 73 \\
(21.9 \%)\end{array}$ & $\begin{array}{l}9 / 35 \\
(25.7 \%)\end{array}$ & $\begin{array}{l}7 / 38 \\
(18.4 \%)\end{array}$ & .452 & $\begin{array}{l}6 / 19 \\
(31.6 \%)\end{array}$ & $\begin{array}{l}5 / 41 \\
(12.2 \%)\end{array}$ & .071 & - & $\begin{array}{l}4 / 27 \\
(14.8 \%)\end{array}$ & $\begin{array}{l}0 / 6 \\
(0 \%)\end{array}$ & $\begin{array}{l}0 / 1 \\
(0 \%)\end{array}$ & $\begin{array}{l}1 / 7 \\
(14.3 \%)\end{array}$ & .759 \\
\hline $\begin{array}{l}\text { Upper } \\
\text { extremity } \\
\text { ataxia }\end{array}$ & $\begin{array}{l}4 / 72 \\
(5.6 \%)\end{array}$ & $\begin{array}{l}1 / 35 \\
(2.8 \%)\end{array}$ & $\begin{array}{l}3 / 37 \\
(8.1 \%)\end{array}$ & .331 & $\begin{array}{l}0 / 19 \\
(0 \%)\end{array}$ & $\begin{array}{l}4 / 42 \\
(9.5 \%)\end{array}$ & .162 & - & $\begin{array}{l}2 / 27 \\
(7.4 \%)\end{array}$ & $\begin{array}{l}1 / 7 \\
(14.3 \%)\end{array}$ & $\begin{array}{l}0 / 1 \\
(0 \%)\end{array}$ & $\begin{array}{l}1 / 7 \\
(14.3 \%)\end{array}$ & .893 \\
\hline $\begin{array}{l}\text { Upper } \\
\text { extremity } \\
\text { Intent tremor }\end{array}$ & $\begin{array}{l}2 / 72 \\
(2.8 \%)\end{array}$ & $\begin{array}{l}0 / 35 \\
(0 \%)\end{array}$ & $\begin{array}{l}2 / 37 \\
(5.4 \%)\end{array}$ & .227 & $\begin{array}{l}0 / 19 \\
(0 \%)\end{array}$ & $\begin{array}{l}2 / 42 \\
(4.8 \%)\end{array}$ & .490 & - & $\begin{array}{l}1 / 27 \\
(3.7 \%)\end{array}$ & $\begin{array}{l}0 / 7 \\
(0 \%)\end{array}$ & $\begin{array}{l}0 / 1 \\
(0 \%)\end{array}$ & $\begin{array}{l}1 / 7 \\
(14.3 \%)\end{array}$ & .331 \\
\hline Seizures & $\begin{array}{l}2 / 71 \\
(2.8 \%)\end{array}$ & $\begin{array}{l}0 / 34 \\
(0 \%)\end{array}$ & $\begin{array}{l}2 / 37 \\
(5.4 \%)\end{array}$ & .334 & $\begin{array}{l}0 / 19 \\
(0 \%)\end{array}$ & $\begin{array}{l}1 / 41 \\
(2.4 \%)\end{array}$ & .492 & - & $\begin{array}{l}1 / 27 \\
(3.7 \%)\end{array}$ & $\begin{array}{l}0 / 6 \\
(0 \%)\end{array}$ & $\begin{array}{l}0 / 1 \\
(0 \%)\end{array}$ & $\begin{array}{l}0 / 7 \\
(0 \%)\end{array}$ & .912 \\
\hline $\begin{array}{l}\text { Skeletal } \\
\text { abnormality }\end{array}$ & $\begin{array}{l}4 / 69 \\
(5.8 \%) \\
\end{array}$ & $\begin{array}{l}2 / 33 \\
(6.1 \%) \\
\end{array}$ & $\begin{array}{l}2 / 36 \\
(5.5 \%)\end{array}$ & .929 & $\begin{array}{l}0 / 19 \\
(0 \%) \\
\end{array}$ & $\begin{array}{l}3 / 40 \\
(7.5 \%)\end{array}$ & .220 & - & $\begin{array}{l}2 / 27 \\
(7.4 \%) \\
\end{array}$ & $\begin{array}{l}0 / 6 \\
(0 \%)\end{array}$ & - & $\begin{array}{l}1 / 7 \\
(14.3 \%)\end{array}$ & .621 \\
\hline $\begin{array}{l}\text { Amyotrophy } \\
\text { or lower } \\
\text { motor neuron } \\
\text { features }\end{array}$ & $\begin{array}{l}6 / 71 \\
(8.5 \%)\end{array}$ & $\begin{array}{l}5 / 35 \\
(14.3 \%)\end{array}$ & $\begin{array}{l}1 / 36 \\
(2.8 \%)\end{array}$ & .081 & $\begin{array}{l}1 / 12 \\
(8.3 \%)\end{array}$ & $\begin{array}{l}3 / 19 \\
(15.8 \%)\end{array}$ & .542 & - & $\begin{array}{l}3 / 33 \\
(9.1 \%)\end{array}$ & $\begin{array}{l}0 / 6 \\
(0 \%)\end{array}$ & - & $\begin{array}{l}1 / 8 \\
(12.5 \%)\end{array}$ & .823 \\
\hline $\begin{array}{l}\text { Abnormal } \\
\text { brain MRI }\end{array}$ & $\begin{array}{l}6 / 48 \\
(12.5 \%)\end{array}$ & $\begin{array}{l}4 / 28 \\
(14.3 \%)\end{array}$ & $\begin{array}{l}2 / 20 \\
(10 \%)\end{array}$ & .658 & $\begin{array}{l}3 / 13 \\
(23.1 \%)\end{array}$ & $\begin{array}{l}3 / 32 \\
(9.4 \%)\end{array}$ & .220 & - & $\begin{array}{l}2 / 20 \\
(10 \%)\end{array}$ & $\begin{array}{l}0 / 5 \\
(0 \%)\end{array}$ & - & $\begin{array}{l}1 / 7 \\
(14.3 \%)\end{array}$ & .696 \\
\hline $\begin{array}{l}\text { Abnormal } \\
\text { spine MRI }\end{array}$ & $\begin{array}{l}8 / 53 \\
(15.1 \%)\end{array}$ & $\begin{array}{l}4 / 30 \\
(13.3 \%)\end{array}$ & $\begin{array}{l}4 / 23 \\
(17.4 \%)\end{array}$ & .683 & $\begin{array}{l}2 / 15 \\
(13.3 \%)\end{array}$ & $\begin{array}{l}6 / 32 \\
(18.8 \%)\end{array}$ & .645 & - & $\begin{array}{l}4 / 17 \\
(23.5 \%)\end{array}$ & $\begin{array}{l}1 / 9 \\
(11.1 \%)\end{array}$ & - & $\begin{array}{l}1 / 6 \\
(16.7 \%)\end{array}$ & .735 \\
\hline
\end{tabular}

Bonferroni corrected $\mathrm{p}$ value: 0.0017 . 
SD, standard deviation; SPRS, Spastic Paraplegia Rating Scale; MRI, magnetic resonance imaging; n, number; LoF, loss of function, MIT, microtubule interacting and trafficking; AAA, ATPase associated with various cellular activities; ATP, adenosine triphosphate.

${ }^{\mathrm{a}}$ InterPro (IPR) number: IPR036181; ${ }^{\mathrm{b}}$ IPR003593; ${ }^{\mathrm{c}}$ IPR041569; ${ }^{\mathrm{d}}$ IPR015415 
medRxiv preprint doi: https://doi.org/10.1101/2021.07.20.21259482; this version posted July 20, 2021. The copyright holder for this preprint (which was not certified by peer review) is the author/funder, who has granted medRxiv a license to display the preprint in perpetuity.

It is made available under a CC-BY 4.0 International license .

Table 2. Mutations identified in the current study and their characteristics.

\begin{tabular}{|c|c|c|c|c|c|}
\hline $\begin{array}{l}\text { Nucleotide } \\
\text { Change }\end{array}$ & Amino acid Change & $\begin{array}{l}\text { Number } \\
\text { of } \\
\text { Families }\end{array}$ & $\begin{array}{l}\text { Number } \\
\text { of } \\
\text { Patients }\end{array}$ & $\begin{array}{l}\mathrm{AF} \\
\text { in gnomAD }\end{array}$ & $\begin{array}{l}\text { Pathogenicity } \\
\text { (VarSome) }\end{array}$ \\
\hline c. $127 \mathrm{G}>\mathrm{T}$ & p.(Glu43Ter) & 1 & 1 & NR & Pathogenic \\
\hline c. $153 \mathrm{C}>\mathrm{G}$ & p.(Tyr51Ter) & 1 & 1 & NR & Pathogenic \\
\hline c. $231 \mathrm{G}>\mathrm{A}$ & p.(Trp77Ter) & 1 & 1 & NR & Pathogenic \\
\hline c. $562 \mathrm{delG}$ & $\begin{array}{l}\text { p.(Ala188Profs } \\
\text { Ter8) }\end{array}$ & 1 & 1 & NR & Pathogenic \\
\hline c. $687 \mathrm{delT}$ & $\begin{array}{l}\text { p.(Ser229Argfs } \\
\text { Ter11) }\end{array}$ & 1 & 1 & NR & Pathogenic \\
\hline c. $869 \mathrm{~A}>\mathrm{G}$ & p.(Lys290Arg) & 1 & 1 & NR & $\begin{array}{l}\text { Likely } \\
\text { Pathogenic }\end{array}$ \\
\hline c. $1098 \mathrm{delG}$ & $\begin{array}{l}\text { p.(Glu366Aspfs } \\
\text { Ter28) }\end{array}$ & 1 & 1 & NR & Pathogenic \\
\hline c. $1111 \mathrm{C}>\mathrm{T}$ & p.(Leu371Phe) & 2 & 2 & NR & Pathogenic \\
\hline c. $1112 \mathrm{~T}>\mathrm{C}$ & p.(Leu371Pro) & 1 & 1 & NR & Pathogenic \\
\hline c. $1139 \mathrm{~T}>\mathrm{C}$ & p.(Leu380Pro) & 1 & 1 & NR & $\begin{array}{l}\text { Likely } \\
\text { Pathogenic }\end{array}$ \\
\hline $\begin{array}{l}\text { c.1144_1145 } \\
\text { insGTC }\end{array}$ & $\begin{array}{l}\text { p.(Gly382_Pro383 } \\
\text { insArg) }\end{array}$ & 1 & 2 & NR & - \\
\hline c. $1158 \mathrm{~T}>\mathrm{G}$ & p.(Asn386Lys) & 1 & 1 & NR & Pathogenic \\
\hline c. $1196 \mathrm{C}>\mathrm{T}$ & p.(Ser399Leu) & 3 & 8 & NR & Pathogenic \\
\hline c. $1209 \mathrm{C}>\mathrm{A}$ & p.(Phe403Leu) & 2 & 5 & NR & $\begin{array}{l}\text { Likely } \\
\text { Pathogenic }\end{array}$ \\
\hline c.1212_1216del & $\begin{array}{l}\text { p.(Asn405Lysfs } \\
\text { Ter36) }\end{array}$ & 1 & 1 & NR & 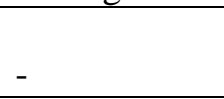 \\
\hline c. $1220 \mathrm{G}>\mathrm{A}$ & p.(Ser407Asn) & 1 & 1 & NR & Pathogenic \\
\hline c. $1242 \mathrm{~A}>\mathrm{G}$ & p.(Lys414Lys) & 2 & 3 & NR & $\begin{array}{l}\text { Uncertain } \\
\text { significance }\end{array}$ \\
\hline c. $1276 \mathrm{C}>\mathrm{G}$ & p.(Leu426Val) & 1 & 1 & NR & Pathogenic \\
\hline c. $1300 \mathrm{C}>\mathrm{T}$ & p.(Gln434Ter) & 1 & 1 & NR & Pathogenic \\
\hline c. $1321+1 \mathrm{G}>\mathrm{A}$ & & 1 & 2 & NR & Pathogenic \\
\hline $\begin{array}{l}\text { c.1356_1357 } \\
\text { insGGG }\end{array}$ & p.(Gly452dup) & 1 & 1 & NR & - \\
\hline c. $1378 \mathrm{C}>\mathrm{T}$ & p.(Arg460Cys) & 1 & 1 & NR & Pathogenic \\
\hline c. $1385 \mathrm{~A}>\mathrm{G}$ & p.(Lys462Arg) & 1 & 1 & NR & Pathogenic \\
\hline c. $1466 C>T$ & p.(Pro489Leu) & 1 & 4 & NR & $\begin{array}{l}\text { Likely } \\
\text { Pathogenic }\end{array}$ \\
\hline $\begin{array}{l}\text { c.1492_1493 } \\
\text { del }\end{array}$ & $\begin{array}{l}\text { p.(Arg498Alafs } \\
\text { Ter30) }\end{array}$ & 1 & 1 & NR & Pathogenic \\
\hline c. $1493+2 \mathrm{~T}>\mathrm{A}$ & & 1 & 1 & NR & Pathogenic \\
\hline
\end{tabular}


medRxiv preprint doi: https://doi.org/10.1101/2021.07.20.21259482; this version posted July 20, 2021. The copyright holder for this preprint (which was not certified by peer review) is the author/funder, who has granted medRxiv a license to display the preprint in perpetuity.

It is made available under a CC-BY 4.0 International license .

\begin{tabular}{|l|l|l|l|l|l|}
\hline c. $1495 \mathrm{C}>\mathrm{T}$ & p.(Arg499Cys) & 2 & 4 & NR & Pathogenic \\
\hline c. $1496 \mathrm{G}>\mathrm{A}$ & p.(Arg499His) & 4 & 4 & NR & Pathogenic \\
\hline c. $1507 \mathrm{C}>\mathrm{T}$ & p.(Arg503Trp) & 3 & 4 & $4.82 \mathrm{E}-06$ & Pathogenic \\
\hline c. $1537-2 \mathrm{~A}>\mathrm{G}$ & & 1 & 7 & NR & Pathogenic \\
\hline c. $1610 \mathrm{~T}>\mathrm{G}$ & p.(Leu537Arg) & 1 & 1 & NR & Pathogenic \\
\hline c. $1676 \mathrm{G}>\mathrm{A}$ & p.(Gly559Asp) & 8 & 15 & NR & Pathogenic \\
\hline c. $1684 \mathrm{C}>\mathrm{T}$ & p.(Arg562Ter) & 1 & 2 & NR & Pathogenic \\
\hline c. $1685 \mathrm{G}>\mathrm{A}$ & p.(Arg562Gln) & 1 & 1 & NR & Pathogenic \\
\hline $\begin{array}{l}\text { c. } 1729-1 \mathrm{G}>\mathrm{C} \\
\text { c. } 1741 \mathrm{C}>\mathrm{T}\end{array}$ & & 2 & 2 & NR & Pathogenic \\
\hline $\begin{array}{l}\text { c. } 1790 \mathrm{delG} \\
\text { c. } 1844 \mathrm{C}>\mathrm{T}\end{array}$ & p.(Arg581Ter) & 2 & 2 & $4.81 \mathrm{E}-06$ & Pathogenic \\
\hline Tel exon 1 & p.(Thr615Ile) & 1 & 3 & NR & Pathogenic \\
\hline $\begin{array}{l}\text { del exons } \\
5-7\end{array}$ & & 1 & 1 & NR & $\begin{array}{l}\text { Likely } \\
\text { Pathogenic }\end{array}$ \\
\hline \begin{tabular}{l} 
del exons $16-17$ \\
\hline
\end{tabular} & & 3 & 3 & NR & Pathogenic \\
\hline
\end{tabular}

AAO, age at onset; UNK, unknown; NR, not reported; AF, allele frequency. 
medRxiv preprint doi: https://doi.org/10.1101/2021.07.20.21259482; this version posted July 20, 2021. The copyright holder for this preprint (which was not certified by peer review) is the author/funder, who has granted medRxiv a license to display the preprint in perpetuity.

It is made available under a CC-BY 4.0 International license .

Table 3. Frequency of symptoms not attributable to the pure form of hereditary spastic paraplegia in the present study compared to previous studies.

\begin{tabular}{|c|c|c|}
\hline Sign/ Symptom & $\begin{array}{l}\text { Frequency in the } \\
\text { current study }\end{array}$ & Previous studies \\
\hline Learning disabilities & $19.6 \%$ & $\begin{array}{l}4.2 \% \text { intellectual } \\
\text { impairment }{ }^{1} \\
1.5 \% \text { Intellectual } \\
\text { disability } 68\end{array}$ \\
\hline $\begin{array}{l}\text { Speech delay or } \\
\text { abnormality }\end{array}$ & $17 \%$ & $4 / 62(6.5 \%)^{68}$ \\
\hline Dysarthria & $16.4 \%$ & $3 \%^{68}$ \\
\hline Cognitive deficiency & $8.2 \%$ & $\begin{array}{l}\text { Most frequent } \\
\text { additional } \\
\text { manifestation }\end{array}$ \\
\hline $\begin{array}{l}\text { Upper extremity } \\
\text { intention tremor }\end{array}$ & $2.8 \%$ & $\begin{array}{l}\text { Mild arm tremor in } \\
10 \% \text { of patients } 68\end{array}$ \\
\hline Seizure & $2.8 \%$ & Case reports ${ }^{69,75,83,84}$ \\
\hline $\begin{array}{l}\text { Ocular movement } \\
\text { abnormality }\end{array}$ & $1.4 \%$ & Case reports ${ }^{85}$ \\
\hline Swallowing difficulty & $5.6 \%$ & $3 \%{ }^{68}$ \\
\hline Upper limb weak ness & $6.9 \%$ & Case reports ${ }^{80}$ \\
\hline Upper limb ataxia & $5.6 \%$ & Case reports ${ }^{80}$ \\
\hline Peripheral neuropathy & $14.3 \%$ & Case reports ${ }^{86}$ \\
\hline Deafness & $5.6 \%$ & - \\
\hline
\end{tabular}


medRxiv preprint doi: https://doi.org/10.1101/2021.07.20.21259482; this version posted July 20, 2021. The copyright holder for this preprint (which was not certified by peer review) is the author/funder, who has granted medRxiv a license to display the preprint in perpetuity.

It is made available under a CC-BY 4.0 International license .

\section{Figures}
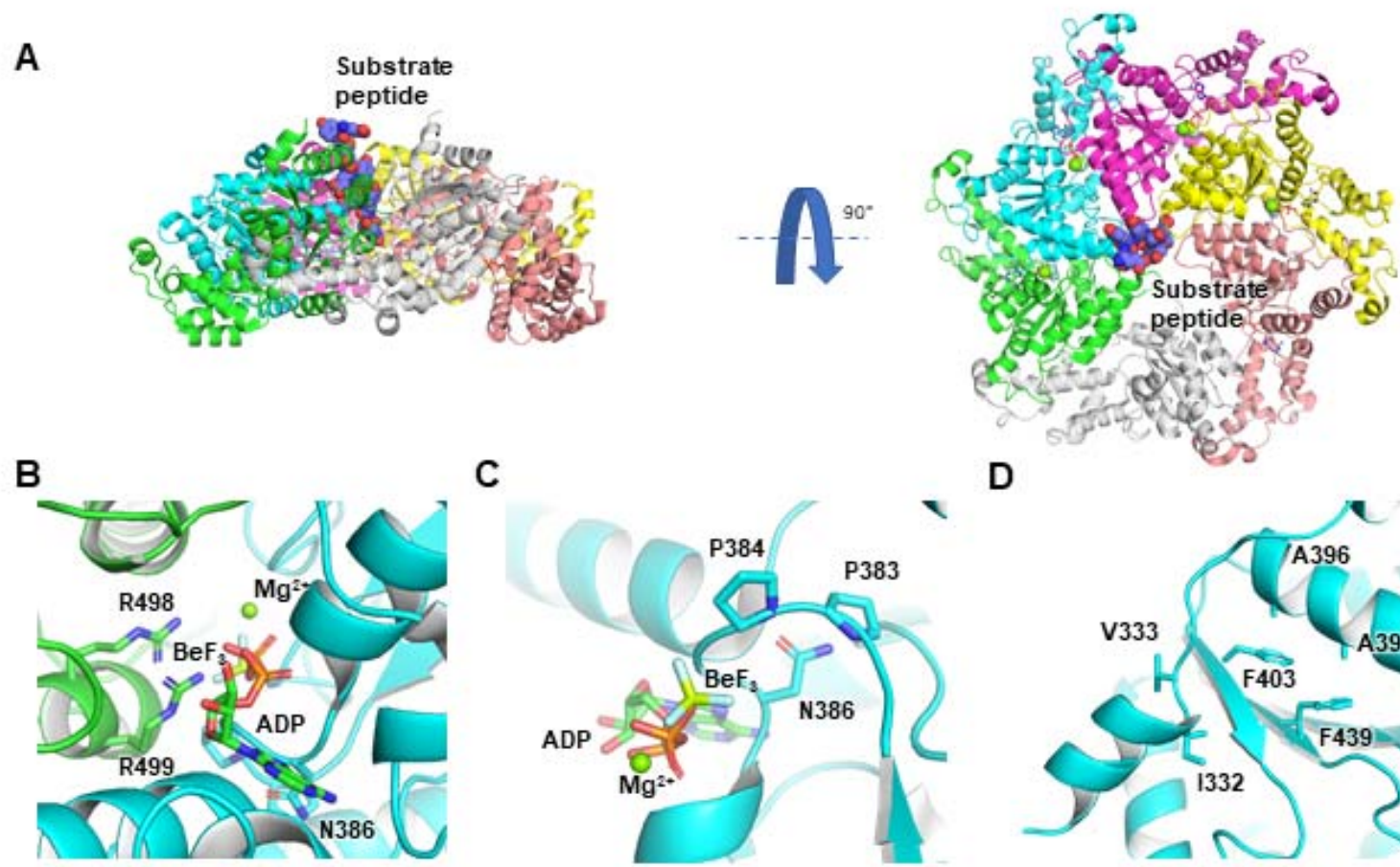

C

D
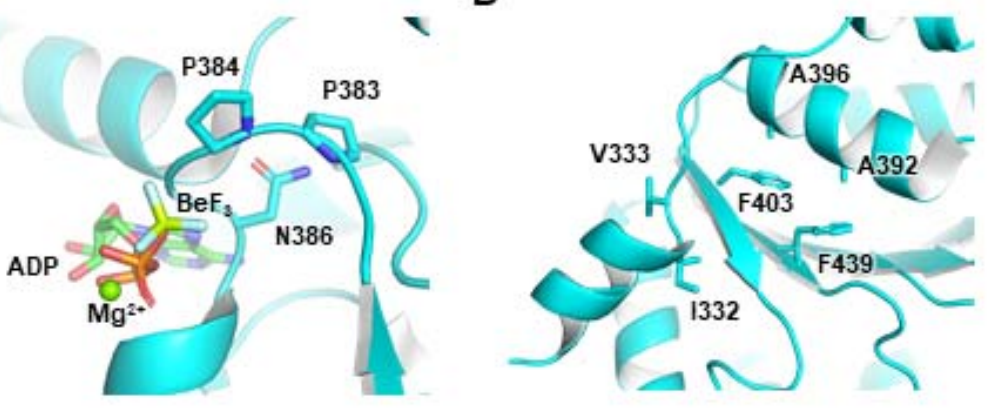

E

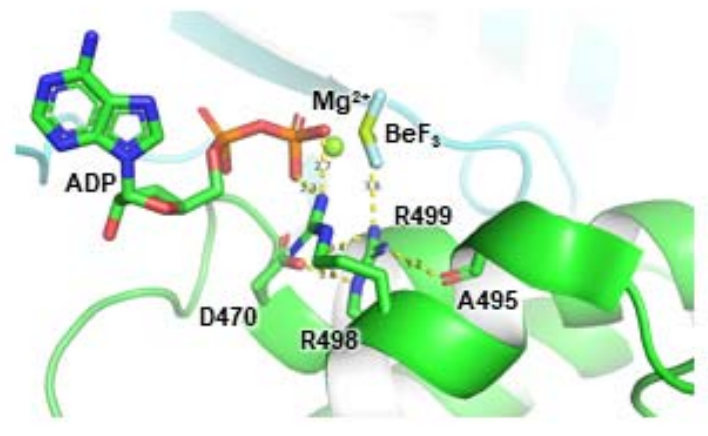

F

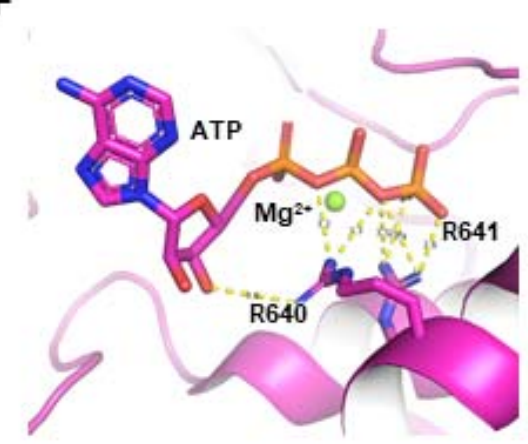

Figure 1. Structural analysis of human SPG4. A: Structure of SPG4 (PDB: 6PEN) forming a homohexameric assembly. The substrate peptide is shown as violet spheres. B: The interface between subunit A (green) and B (cyan) forms an active site. C: Loop $382-389$ is part of the nucleotide binding pocket. D: $\beta$-strand ${ }_{402-406}$ stabilizes helix ${ }_{387-399}$ and the $\mathrm{C}$-terminal residues of this structure. E: Arg498 and Arg499 interact with ADP, BrF 3 , Asp470 and Ala495's main chain, stabilizing the nucleotide and the active site. Polar interactions are shown as yellow dotted lines. F: D. melanogaster Spastin structure (PDB: 6P07) was solved with an ATP molecule in the active site. Arg640 and Arg641, homologous to Arg498 and Arg499 in human Spastin, are coordinating ATP in the active site. 


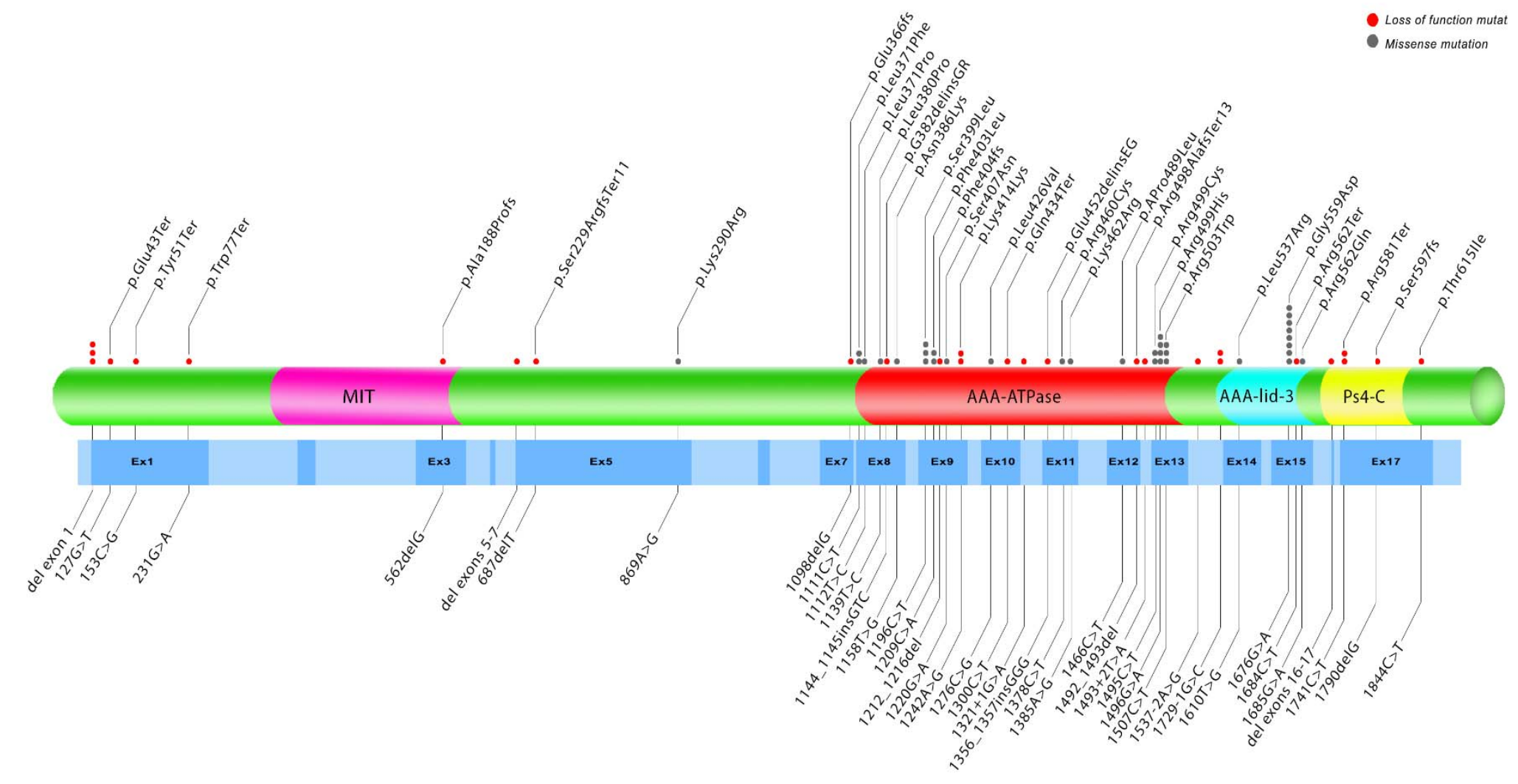

Figure 2. Schematic figure of the location of SPG4 mutations in the current study. The schematic on top represents the spastin protein. Functional domains are demonstrated in different colors, including MIT (violet), AAA-ATPase (red), AAA-lid-3 (cyan), and Ps4-C (yellow). Mutations resulting in loss of function and missense mutations are indicated with red and grey circles respectively. The number of circles in a column demonstrate the number of families that carried each mutation. The bottom schematic represents the cDNA of SPG4. Exons (indicated with Ex) are represented by dark blue and introns by light blue. 


\section{Supplementary Tables and Figures}

Supplementary Table 1. Genes that are known or suspected to be involved in HSP or other similar disorders.

Supplementary Table 2. Copy number variations (CNVs) in the current study.

Supplementary Table 3. Signs and symptoms seen more frequently in patients harboring the p.(Arg499His) mutation.

Supplementary Table 4. Clinical manifestations of the family with probable biallelic inheritance. Patients 1 and 2 had undergone whole exome sequencing and were compound heterozygous carriers of the novel pathogenic mutation p.(Ser597ThrfsTer3), and the p.(Ser44Leu) variant. Sample from patient 3 was not available.

Supplementary Table 5. Characteristics of SPG4 patients with deafness.

Supplementary Figure 1. Distribution of age at onset in the cohort. The onset of SPG4 mostly occurs in the first five years of life, and between 35-44 years of age.

Supplementary Figure 2. Sanger sequencing results of family with modifier mutation. Mother and father carry the p.(Ser597ThrfsTer3) and p.(Ser44Leu) mutations respectively. Siblings are heterozygote for both mutations. 